\title{
Role of Water in the Lyotropic Liquid Crystalline Mesophase of Lithium Salts and Non-ionic Surfactants
}

\author{
Ezgi Y1lmaz Topuzlu, Halil I. Okur, Burak Ulgut, and Ömer Dag* \\ Cite This: Langmuir 2021, 37, 14443-14453 \\ Read Online
}

ABSTRACT: The lyotropic liquid crystalline (LLC) mesophase forms upon evaporation of water from aqueous solutions of $\mathrm{LiX}$ salts ( $\mathrm{X}$ is $\mathrm{Cl}^{-}, \mathrm{Br}^{-}, \mathrm{NO}_{3}^{-}$, or $\mathrm{SCN}^{-}$) and a surfactant $\left[\mathrm{C}_{12} \mathrm{H}_{25}\left(\mathrm{OCH}_{2} \mathrm{CH}_{2}\right)_{10} \mathrm{OH}\right.$, abbreviated as $\left.\mathrm{C}_{12} \mathrm{E}_{10}\right]$. The LiX/ $\mathrm{C}_{12} \mathrm{E}_{10} / \mathrm{H}_{2} \mathrm{O}$ aqueous solutions have been monitored (during evaporation of their excess water to obtain stable LLC mesophases) by gravimetric, spectroscopic, and conductivity measurements to elucidate the role of water in these mesophases. The water/salt molar ratio in stable mesophases changes from 1.5 to 8.0 , depending on the counteranion of the salt and the ambient humidity of the laboratory. The $\mathrm{LiX} / \mathrm{C}_{12} \mathrm{E}_{10} / \mathrm{H}_{2} \mathrm{O}$ LLC mesophases lose water at lower humidity levels and absorb water at

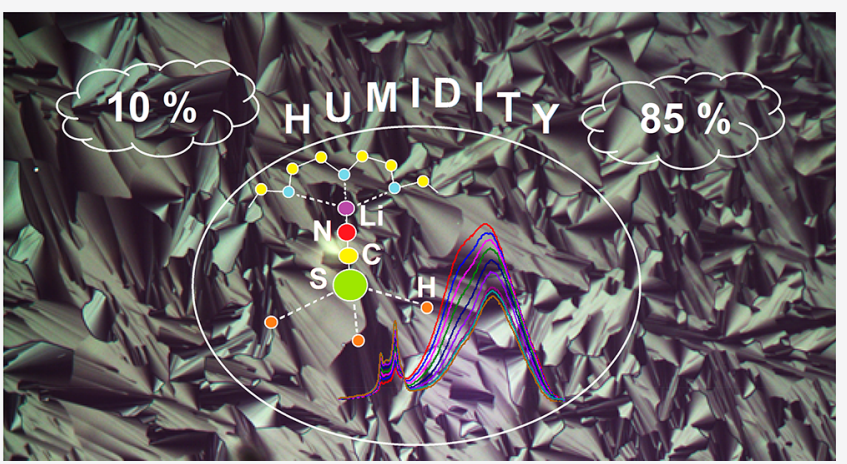
higher humidity levels. The LiCl-containing mesophase holds as few as four structural water molecules per $\mathrm{LiCl}$, whereas the $\mathrm{LiNO}_{3}$ mesophase holds 1.5 waters per salt (least among those assessed). This ratio strongly depends on the atmospheric humidity level; the water/LiX mole ratio increases by $0.08 \pm 0.01 \mathrm{H}_{2} \mathrm{O}$ in the LLC mesophases per percent humidity unit. Surprisingly, the LLC mesophases are stable (no salt leaching) in broad humidity $(10-85 \%)$ and salt/surfactant mole ratio $\left(2-10 \mathrm{LiX} / \mathrm{C}_{12} \mathrm{E}_{10}\right)$ ranges. Attenuated total reflectance Fourier transform infrared spectroscopic data show that the water molecules in the mesophase interact with salt species more strongly in the $\mathrm{LiCl}$ mesophase and more weakly in the case of the nitrate ion, which is evident by the shift of the $\mathrm{O}-\mathrm{H}$ stretching band of water. The $\mathrm{O}-\mathrm{H}$ stretching peak position in the mesophases decreases in the order $\nu_{\mathrm{LiCl}}>\nu_{\mathrm{LiBr}}>\nu_{\mathrm{LiSCN}}>\nu_{\mathrm{LiNO}_{3}}$ and accords well with the $\mathrm{H}_{2} \mathrm{O} / \mathrm{LiX}$ mole ratio. The conductivity of the LLC mesophase also responds to the amount of water as well as the nature of the counteranion $\left(\mathrm{X}^{-}\right)$. The conductivity decreases in the order $\sigma_{\mathrm{LiCl}}>\sigma_{\mathrm{LiBr}}>\sigma_{\mathrm{LiNO}_{3}}>\sigma_{\mathrm{LiSCN}}$ at low salt mole ratios and in the order $\sigma_{\mathrm{LiBr}}>\sigma_{\mathrm{LiCl}}>$ $\sigma_{\mathrm{LiNO}_{3}}>\sigma_{\mathrm{LiSCN}}$ at higher ratios due to structural changes in the mesophase.

\section{INTRODUCTION}

Electrochemical cells, consisting of three major components, an anode, a cathode, and an electrolyte, are widely employed to store and convert clean and renewable energy. ${ }^{1}$ Electrolytes are important components of these cells because the ion transport and electrode contacts occur within and with the electrolyte. ${ }^{2}$ For these applications, electrolytes must have good ion conductivity, large electrochemical windows, low toxicity, low volatility, low flammability, and high viscosity. ${ }^{3}$ Most of the organic-based and water-based electrolytes fail in one or more of these realms. ${ }^{4}$ Gel electrolytes could be a good alternative to solution-based electrolytes if their conductivity issues could be resolved. ${ }^{5-12}$ Liquid crystalline electrolytes (LCEs) have also been widely investigated in the literature as gel electrolytes. ${ }^{8-24}$ The liquid crystalline gel electrolytes are in general in two different forms, thermotropic ${ }^{12}$ and lyotropic liquid crystalline (LLC), ${ }^{17-19}$ such as salt/surfactant LLC mesophases. ${ }^{20-22}$ LCEs have been employed as gel electrolytes in many ways $^{15-24}$ such as optical modulation of graphene, effectively switching electrochromic devices, and dye-sensitized solar cells.
Salt/surfactant mesophases make up an important class of materials that could be used as gel electrolytes in electrochemical systems and constitute an important platform ${ }^{20-22}$ for the synthesis of mesoporous materials. ${ }^{25-28}$ Salts in their molten state or as a highly saturated solution can organize surfactants into liquid crystalline phases. ${ }^{20,29-31}$ In the salt/ surfactant LLC mesophases, molten salt or saturated salt solutions act as a nonvolatile solvent as one of the major components of the phase. Therefore, the salt/surfactant LLC mesophase differs from the salt-containing and salt free water/ surfactant LLC mesophase ${ }^{32-35}$ in terms of phase stability and usability in material synthesis and design. ${ }^{25-28}$ Moreover, one

Received: September 12, 2021

Revised: November 22, 2021

Published: December 3, 2021 

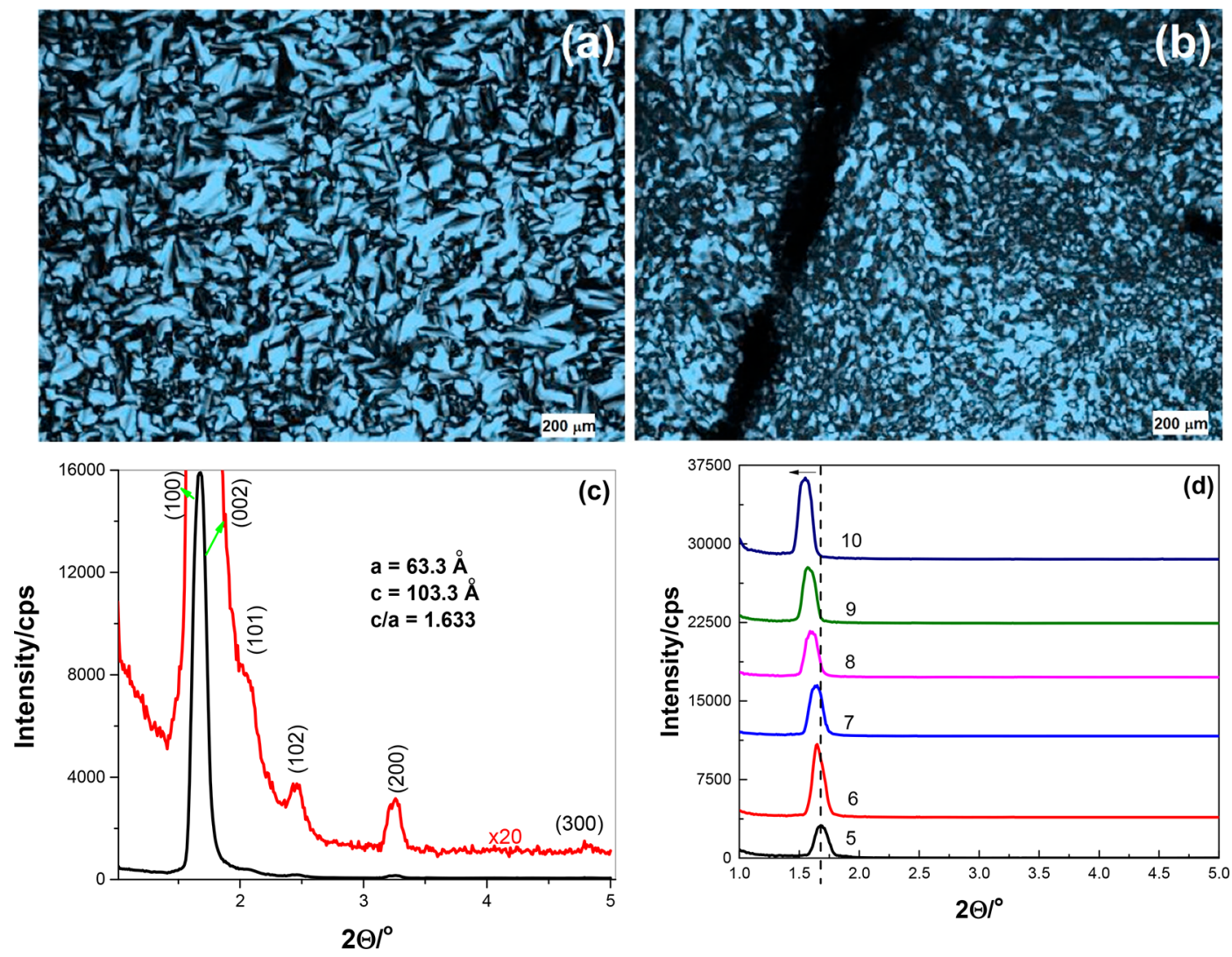

Figure 1. POM images of (a) $2 \mathrm{LiCl} / \mathrm{C}_{12} \mathrm{E}_{10} / \mathrm{H}_{2} \mathrm{O}$ and (b) $3 \mathrm{LiBr} / \mathrm{C}_{12} \mathrm{E}_{10} / \mathrm{H}_{2} \mathrm{O}$ systems and small angle XRD patterns of $(\mathrm{c}) 4 \mathrm{LiCl} / \mathrm{C}_{12} \mathrm{E}_{10} / \mathrm{H}_{2} \mathrm{O}$ (red line, magnified 20 times) and (d) $5-10 \mathrm{LiBr} / \mathrm{C}_{12} \mathrm{E}_{10} / \mathrm{H}_{2} \mathrm{O}$ (aged for 8 months) systems.

can also use a volatile solvent in addition to the salt/surfactant mixture to obtain homogeneous solutions. The solutions spread over any substrate to afford the salt/surfactant mesophase as thin films. ${ }^{25-28}$ Thinner gel films can be prepared by simply diluting the solution or spin coating solutions at a higher speed. The LLC film can be as thin as tens of nanometres as determined by this approach. This gives flexibility and applicability to the LLC phases. Another important aspect in such a self-assembly process is the amount of water in the mesophase. The amount of water determines the structure, stability, and conductivity of these mesophases. Therefore, investigating the role of water and understanding the specific effects of ions on water are important for the development of water-based LLC gel electrolytes.

Specific ion effects were first reported by Hofmeister in 1888 for the separation of proteins. ${ }^{36,37}$ Although substantial effort has been focused on exploring the underlying mechanisms of the reoccurring ion series, there is still no unified theory to explain the role of ions in colloidal and molecular assembly systems in various aqueous media. ${ }^{38-42}$ The Hofmeister series $\left(\mathrm{CO}_{3}{ }^{2-}>\mathrm{SO}_{4}{ }^{2-}>\mathrm{S}_{2} \mathrm{O}_{3}{ }^{2-}>\mathrm{HPO}_{4}{ }^{2-}>\mathrm{H}_{2} \mathrm{PO}_{4}{ }^{-}>\mathrm{F}^{-}>\right.$ $\left.\mathrm{CH}_{3} \mathrm{COO}^{-}>\mathrm{Cl}^{-}>\mathrm{Br}^{-}>\mathrm{NO}_{3}^{-}>\mathrm{I}^{-}>\mathrm{ClO}_{4}^{-}>\mathrm{SCN}^{-}>\mathrm{I}_{3}^{-}\right)$ has been expanded over the years, including many anions and cations using different macromolecules and colloids. ${ }^{4-50}$ This work focuses on only the effect of anions. In this series, the anions on the left-hand side of the series are kosmotropic and enhance the structure of water (also termed structure makers) and the other end is chaotropic and breaks the structure of water (structure breakers) and interacts with the macromolecules via direct binding or through their hydration water molecules. ${ }^{43-50}$ Recent experimental results show that these behaviors dominate on the ion and its hydration shell(s), yet there is no probe for exploring the bulk water structure. The literature data were obtained by probing the local $\mathrm{O}-\mathrm{H}$ stretching or bending modes by surface selective techniques such as vibrational sum frequency generation and their dynamics explored by two-dimensional (2D) infrared (IR) spectroscopy. ${ }^{51-54}$

Here, we examine $\mathrm{LiX} / \mathrm{C}_{12} \mathrm{E}_{1 \mathrm{O}}$ LLC systems \{where $\mathrm{X}$ is $\mathrm{Cl}^{-}, \mathrm{Br}^{-}, \mathrm{NO}_{3}{ }^{-}$, or $\mathrm{SCN}^{-}$and $\mathrm{C}_{12} \mathrm{E}_{1 \mathrm{O}}$ refers to $\left.\left[\mathrm{C}_{12} \mathrm{H}_{25}\left(\mathrm{OCH}_{2} \mathrm{CH}_{2}\right)_{10} \mathrm{OH}\right]\right\}$ that could be employed to explore the function of water and its interaction with ions and surfactant domains using gravimetric, spectroscopic, and conductivity measurements. Evaporation from the salt/ surfactant solutions, prepared in excess water, is monitored over time until the gel phase forms as determined by gravimetric, spectroscopic, and conductivity techniques. Notice that at the end of this process, the LLC mesophase reaches an equilibrium with the surrounding water (atmospheric water) and contains the hydration water that is identified by spectroscopic (ATR-FTIR) and gravimetric techniques. These LLC mesophases display high ion conductivity with the potential to serve as an electrolyte for electrochemical cells. The LLC mesophase can also serve as a model system for exploring the specific effects of ions under water-starved conditions.

\section{EXPERIMENTAL SECTION}

Materials. All chemicals used in this work were Sigma-Aldrich grade and used as received with purities of $\geq 99 \%$. Deionized water was obtained from a Millipore Synergy 185 water purifier. 
Preparation of the $\mathrm{LiX} / \mathrm{xH}_{2} \mathrm{O} / \mathrm{C}_{12} \mathrm{EO}_{10}$ Solutions. Predetermined amounts of salt $\left(\mathrm{LiCl}, \mathrm{LiBr}, \mathrm{LiNO}_{3}\right.$, and $\left.\mathrm{LiSCN}\right)$, surfactant $\left[\mathrm{C}_{12} \mathrm{H}_{25}\left(\mathrm{OCH}_{2} \mathrm{CH}_{2}\right)_{10} \mathrm{OH}\right.$ represented as $\left.\mathrm{C}_{12} \mathrm{E}_{10}\right]$, and $5 \mathrm{~g}$ of water are placed in a vial and stirred for $\geq 6 \mathrm{~h}$ to afford homogeneous solutions. Compositions of all of the $\mathrm{LiCl}, \mathrm{LiBr}, \mathrm{LiNO}_{3}$, and $\mathrm{LiSCN}$ solutions used in this work are listed in Tables $\mathrm{S} 1-\mathrm{S} 4$, respectively.

Preparation of $\mathrm{LiX} / \mathrm{C}_{12} \mathrm{E}_{10} / \mathrm{H}_{2} \mathrm{O}$ LLC Mesophases. The solutions were coated over glass slides as films, and then the excess water was evaporated for $24 \mathrm{~h}$ under ambient laboratory conditions to afford the LLC mesophase.

Instrumentation. Polarized optical microscope (POM) images were recorded using a ZEISS Axio Scope Al polarizing optical microscope. The X-ray diffraction patterns were recorded by using a Rigaku Miniflex diffractometer, having a high-power $\mathrm{Cu} \mathrm{K} \alpha$ source operating at $30 \mathrm{kV}$ and $15 \mathrm{~mA}$ with a wavelength of $1.5405 \AA$. The measurements were conducted by spreading the samples on clean glass slides by either spin-coating at different spin rates or drop casting. Small angle X-ray diffraction (XRD) patterns were collected from $1^{\circ}$ to $5^{\circ}$ and high-angle XRD patterns were collected from $5^{\circ}$ to $60^{\circ}, 2 \theta$, with scan speeds of $0.5^{\circ} / \mathrm{min}$ and $5.0^{\circ} / \mathrm{min}$, respectively. Attenuated total reflectance Fourier transform infrared (ATR-FTIR) spectra were recorded by using a Bruker Alpha-P FT-IR spectrometer with an ATR attachment. The spectra were recorded by dropping the samples on the ATR diamond and recording the spectra over time during the evaporation of water. The humidity-dependent spectra were also recorded by using a homemade setup, in which a saturated salt solution in a vial is placed next to the sample and sealed using a plastic container to adjust the humidity. Saturated solutions of $\mathrm{LiCl}$, $\mathrm{MgCl}_{2}, \mathrm{~K}_{2} \mathrm{CO}_{3}, \mathrm{NaBr}, \mathrm{KI}, \mathrm{NaCl}$, and $\mathrm{KCl}$ salt ensure $11 \%, 33 \%, 43 \%$, $57 \%, 68 \%, 75 \%$, and $85 \%$ humidity on the sample, respectively. ${ }^{55}$ Ion conductivities of the samples were measured by employing ac impedance spectroscopy using a Gamry G750 potentiostat/galvanostat and a homemade conductivity cell. ${ }^{19}$ First, a $0.01 \mathrm{M} \mathrm{KCl}$ standard solution, which has a conductivity of $1.413 \mathrm{mS} / \mathrm{cm}$, is used to determine the cell constant $(K)$ using the conductivity equation $(\sigma=$ $K / R$, where $\sigma$ is the conductivity in siemens per centimeter and $R$ is the measured resistance in ohms) and measured resistance. Then, the same cell is cleaned and reused to measure the resistance of the sample solution at any time during the evaporation of water. The resistance data are converted to time-dependent conductivity by using the predetermined cell constant. The humidity-dependent conductivity data of the gel samples were collected by using the same saturated salt solutions in the vicinity of the conductivity cell in a sealed constant-volume chamber.

\section{RESULTS AND DISCUSSION}

Clear aqueous solutions of $\mathrm{LiX}\left(\mathrm{X}\right.$ is $\mathrm{Cl}^{-}, \mathrm{Br}^{-}, \mathrm{I}^{-}, \mathrm{NO}_{3}{ }^{-}$, or $\mathrm{SCN}^{-}$) and $\mathrm{C}_{12} \mathrm{E}_{10}$ in a broad range of salt amounts ( $\mathrm{LiX} /$ $\mathrm{C}_{12} \mathrm{E}_{10}$ mole ratio of 2-10) were prepared as homogeneous solutions (all ingredients are fully dissolved, especially the surfactant molecules). As a first set of experiments, the solutions were coated over glass substrates for characterization by POM and XRD. Coating and then aging steps ensure the formation of an LLC mesophase. Figure 1 shows characteristic POM images and XRD patterns, recorded using various $\mathrm{LiX} /$ $\mathrm{C}_{12} \mathrm{E}_{10}$ mesophases. Careful inspection of the POM images together with XRD patterns shows that the $\mathrm{LiX} / \mathrm{C}_{12} \mathrm{E}_{10} \mathrm{LLC}$ mesophases have a $2 \mathrm{D}$ hexagonal structure (except LiSCN/ $\mathrm{C}_{12} \mathrm{E}_{10}$ ) at low salt concentrations and display a focal conic fan texture (see Figure 1a). However, increasing the amount of $\mathrm{LiX}$ in the mesophase (such as $4 \mathrm{LiCl} / \mathrm{C}_{12} \mathrm{E}_{10} / 4 m \mathrm{H}_{2} \mathrm{O}$, where $m$ is the $\mathrm{H}_{2} \mathrm{O} / \mathrm{LiCl}$ mole ratio, and $3 \mathrm{LiBr} / \mathrm{C}_{12} \mathrm{E}_{10} / 3 x \mathrm{H}_{2} \mathrm{O}$, where $x$ is the $\mathrm{LiBr} / \mathrm{C}_{12} \mathrm{E}_{10}$ mole ratio) leads to a change in the texture (see Figure $1 \mathrm{~b}$ ) that is characteristic of a threedimensional (3D) hexagonal mesophase. ${ }^{52}$ The XRD patterns of these samples are also in accord with this transformation (2D to $3 \mathrm{D}$ hexagonal); the diffraction lines [such as (002),
(101) and (102)] that do not exist in the $2 \mathrm{D}$ hexagonal phases appear in the patterns (see Figure 1c). ${ }^{5,57}$ With a further increase in the molar ratio of $\mathrm{LiBr}$ to $>5$, in the $\mathrm{LiBr} / \mathrm{C}_{12} \mathrm{E}_{10} /$ $\mathrm{H}_{2} \mathrm{O}$ LLC, the mesophase becomes cubic and dark under the POM. However, $\mathrm{LiCl}$ and $\mathrm{LiNO}_{3}$ mesophases are hexagonal in all compositions, at $\mathrm{LiX} / \mathrm{C}_{12} \mathrm{E}_{10}$ mole ratios from 2 to 10 . Figure 2 schematically summarizes the phase behavior of LiX/

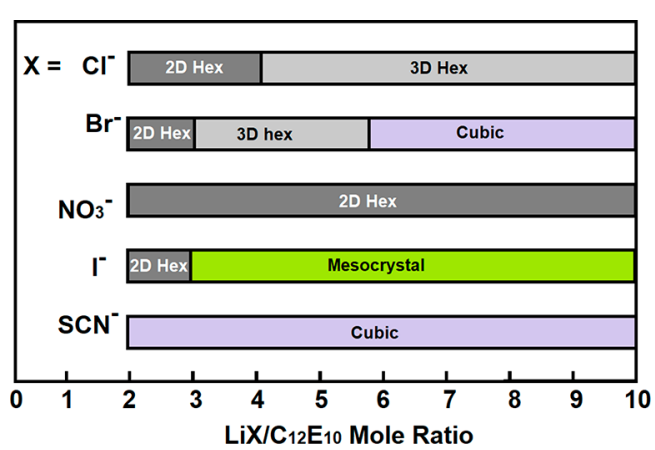

Figure 2. Diagram summarizing the phase behavior of the LiX/ $\mathrm{C}_{12} \mathrm{E}_{10} / \mathrm{H}_{2} \mathrm{O}$ mesophases.

$\mathrm{C}_{12} \mathrm{E}_{10} / \mathrm{H}_{2} \mathrm{O}$ LLC mesophases. Notice that the morphology of the LLC mesophase changes with counteranion (see Figure 2). It is due to the amount of water each ion holds in the mesophase and the change in the ion-water-surfactant interactions (see below). Figure 1d displays a set of diffraction patterns recorded from $\mathrm{LiBr} / \mathrm{C}_{12} \mathrm{E}_{10} / \mathrm{H}_{2} \mathrm{O}$ mesophases. The gradual shift of the main line to smaller angles indicates that increasing the amount of $\mathrm{LiBr}$ in the mesophase also increases the unit cell dimensions that gradually expand to accommodate extra salt/water species in the hydrophilic domains of the mesophase; the typical expansion is $\sim 25 \%$ in the $10 \mathrm{LiBr} /$ $\mathrm{C}_{12} \mathrm{E}_{10}$ mesophase (see Figure 1d). The phase transformation, from $2 \mathrm{D}$ (disordered along the $c$-axis, cylindrical micelle surfactant domains) to $3 \mathrm{D}$ hexagonal (spherical micelle surfactant domains) and to the cubic phase with an increase in salt content, occurs for the same reason; simply, the mesophase expands its hydrophilic domains to accommodate more $\mathrm{LiX} / \mathrm{H}_{2} \mathrm{O}$ species. A similar trend is observed in the $\mathrm{LiI} /$ $\mathrm{C}_{12} \mathrm{E}_{10}$ mesophase that is $2 \mathrm{D}$ hexagonal at low salt concentrations, but the LLC phase transforms into a soft mesocrystal at mole ratios of $>3$. $^{58}$ Moreover, the LiI/ $\mathrm{C}_{12} \mathrm{E}_{10}$ mesophase has been previously investigated in the presence of $\mathrm{I}_{2}$ as a gel electrolyte in dye-sensitized solar cells. ${ }^{59}$ Therefore, we excluded the $\mathrm{LiI} / \mathrm{C}_{12} \mathrm{E}_{10} / \mathrm{H}_{2} \mathrm{O}$ system and $\mathrm{did}$ not investigate it further in this work. The patterns in Figure $\mathrm{S} 1$ show the XRD patterns of the $\mathrm{LiSCN} / \mathrm{C}_{12} \mathrm{E}_{10} / \mathrm{H}_{2} \mathrm{O}$ system at small and large angles. Because the mesophases are dark under $\mathrm{POM}$, it is reasonable to suggest that the $\mathrm{LiSCN} / \mathrm{C}_{12} \mathrm{E}_{10} / \mathrm{H}_{2} \mathrm{O}$ system is cubic at all concentrations. Keeping these basic characterizations in mind, we have investigated each system further to evaluate the amounts of water and its behavior in each LLC system by monitoring the evaporation of water under various conditions using gravimetric, spectroscopic, and conductivity techniques.

First, the $\mathrm{LiX} / \mathrm{C}_{12} \mathrm{E}_{10}$ solutions were prepared in $5 \mathrm{~mL}$ of water. Then, a small amount of each solution was dropped over a balance, and its evaporation of water was gravimetrically monitored for $24 \mathrm{~h}$. Figures 3a shows the weight change of the sample over time for the $\mathrm{LiCl}$ system with a $\mathrm{LiCl} / \mathrm{C}_{12} \mathrm{E}_{10}$ mole ratio of 5 (the other mole ratios and salt systems are given in 

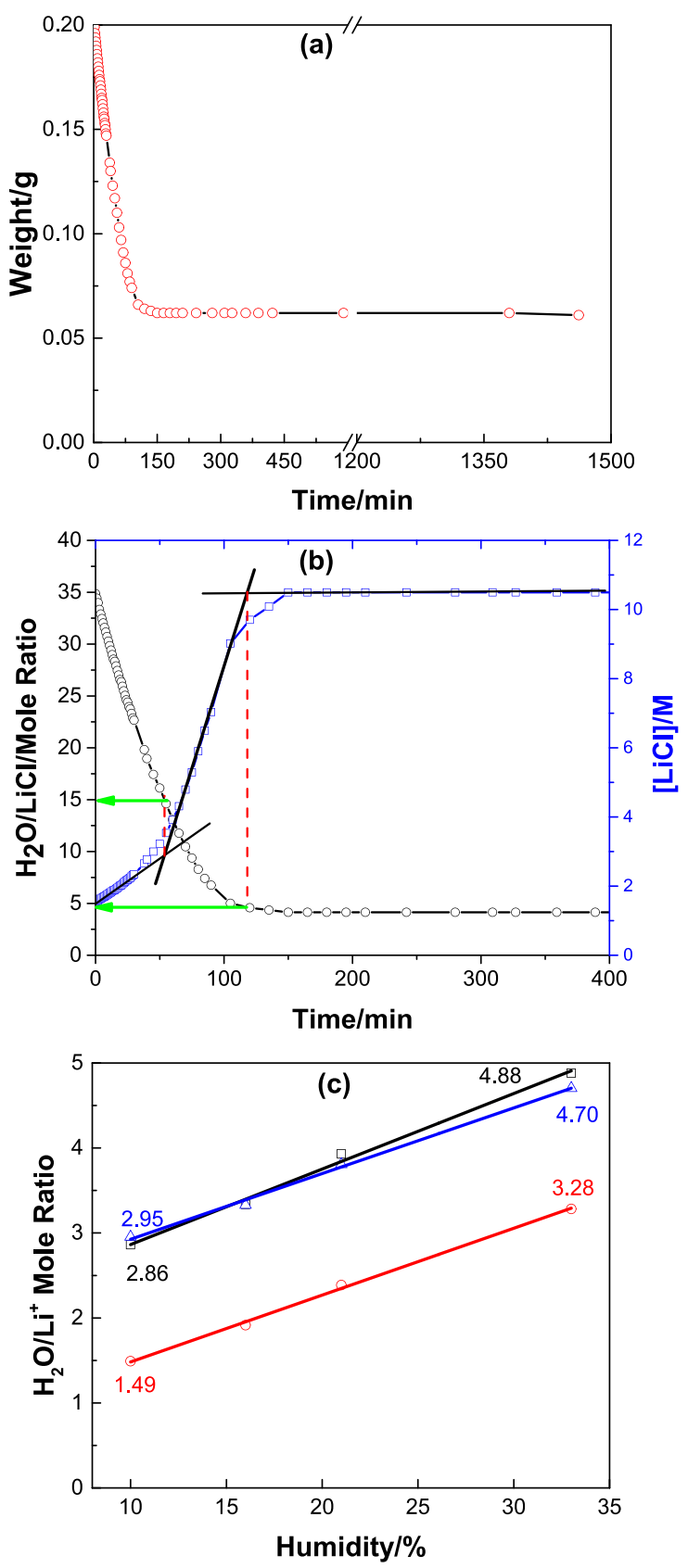

Figure 3. Evaporation of water. (a) Gravimetric data of the $5 \mathrm{LiCl} /$ $\mathrm{C}_{12} \mathrm{E}_{10} / \mathrm{H}_{2} \mathrm{O}$ system (28\% humidity). (b) $\mathrm{H}_{2} \mathrm{O} / \mathrm{LiCl}$ mole ratio and [LiCl] vs time (guide to the eyes) of the $5 \mathrm{LiCl} / \mathrm{C}_{12} \mathrm{E}_{10} / \mathrm{H}_{2} \mathrm{O}$ system. (c) Humidity-dependent $\mathrm{H}_{2} \mathrm{O} / \mathrm{LiX}$ mole ratio of the LLC phases of $5 \mathrm{LiX} / \mathrm{C}_{12} \mathrm{E}_{10} / \mathrm{H}_{2} \mathrm{O}$ samples (fitted to a linear equation; blue for $\mathrm{LiCl}$, black for $\mathrm{LiBr}$, and red for $\mathrm{LiNO}_{3}$ ).

the Supporting Information; see Figures S2-S4). The weight versus time plot drops perfectly linearly and reaches a plateau, where the change stops after $24 \mathrm{~h}$. Because the initial composition of the solution is known and assuming the salt and surfactant do not evaporate and remain unchanged over time, the weight change can be directly attributed to lost water. Therefore, the sum of the weight of salt and surfactant $\left(W_{\mathrm{ss}}\right)$ is known in the initial solution and remains constant during the evaporation of water. The final weight $\left(W_{\mathrm{f}}\right)$ of the sample minus the sum of the salt and surfactant weight of the solution $\left(W_{\mathrm{f}}-W_{\mathrm{ss}}\right)$ is the weight of water $\left(W_{\mathrm{w}}\right)$ that remains in the mesophase. The amount of water in the sample at time $t\left(W_{\mathrm{wt}}\right)$ can also be calculated by simply subtracting $W_{\text {ss }}$ from the weight of the sample $\left(W_{\mathrm{s}}\right)$ at the same time $t\left(W_{\mathrm{w} t}=W_{\mathrm{s}}-\right.$ $\left.W_{\text {ss }}\right)$. Therefore, the $\mathrm{H}_{2} \mathrm{O} / \mathrm{LiX}$ mole ratio can also be calculated at any time (see the plot in Figure 3b). The straight black lines on the plots in Figure 3b and Figures S2-S4 clearly show three regions of evaporation of water with different kinetics. Table 1 shows the calculated $\mathrm{H}_{2} \mathrm{O} / \mathrm{LiX}$ mole ratios of all compositions for all salt/surfactant systems, upon complete evaporation of water. We also evaluated the change in the salt concentration ([LiX], calculated using only $\mathrm{LiX}$ and water) during evaporation of water and plotted the data together with the $\mathrm{H}_{2} \mathrm{O} / \mathrm{LiX}$ mole ratio versus time. The plot of $[\mathrm{LiX}]_{t}$ versus time displays at least three main regions, where the evaporation of water follows different kinetics. In the first region or step, the change in $[\mathrm{LiX}]$ is slow. We assume this is the evaporation of only bulk water; the mixture is still in the liquid phase in this region. In the second region or step, the change is faster and corresponds to a gelation (macroscopically, the liquid mixture transforms into an LLC gel), and in the third region, there is further yet slow evaporation of water from the LLC gel phase. The break points between the regions in the plot also provide valuable information and serve as reference points with regard to evaporation of water, gelation, and stability of the LLC phases. For instance, in the $5 \mathrm{LiCl} / \mathrm{C}_{12} \mathrm{E}_{10}$ sample, the gelation process starts around $15 \mathrm{H}_{2} \mathrm{O} / \mathrm{LiCl}$ and reaches completion around $5 \mathrm{H}_{2} \mathrm{O} / \mathrm{LiCl}$. However, evaporation of water continues in the gel phase and reaches equilibrium around $4 \mathrm{H}_{2} \mathrm{O} / \mathrm{LiCl}$.

From these measurements and calculations, we found that as the $\mathrm{LiX}$ concentration increases in the mesophase, the $\mathrm{H}_{2} \mathrm{O}$ / LiX mole ratio remains almost constant. However, for the salts of more chaotropic anions, such as $\mathrm{LiSCN}$, the $\mathrm{H}_{2} \mathrm{O} / \mathrm{LiSCN}$ mole ratio remains constant at around 1.9 for samples with a $\mathrm{LiSCN} / \mathrm{C}_{12} \mathrm{E}_{10}$ mole ratio of $\leq 5$. However, it gradually increases with a further increase in the amount of LiSCN in the mesophase and reaches 2.7 for samples with a LiSCN/ $\mathrm{C}_{12} \mathrm{E}_{10}$ mole ratio of 10 . However, all $\mathrm{H}_{2} \mathrm{O} / \mathrm{LiX}$ mole ratios are subject to the humidity level of the laboratory. It increases linearly with humidity. This is also clear in the plots in Figure $3 c$. The third region of the evaporation of water corresponds to the gel phase that is stable over a broad range of water contents. This range corresponds to the humidity tolerance region in a stable gel phase. Therefore, we also identified the $\mathrm{H}_{2} \mathrm{O} / \mathrm{LiX}$ mole ratios at different humidities. The humidity levels of the samples were set by keeping the samples in a humidity chamber or in a closed container together with a saturated salt solution that provides a constant humidity at a given temperature.

The humidity-dependent $\mathrm{H}_{2} \mathrm{O} / \mathrm{LiX}$ mole ratios were evaluated using $5 \mathrm{LiX} / \mathrm{C}_{12} \mathrm{E}_{10}$ samples of all four salts. Notice also that the $\mathrm{H}_{2} \mathrm{O} / \mathrm{LiX}$ mole ratio varies from day to day due to the change in the humidity of our laboratory (see Table 1). We picked four different days with four different humidity levels of $10 \%, 16 \%, 21 \%$, and $33 \%$. The plot in Figure $3 \mathrm{c}$ shows that there are slight differences from salt to salt, but the change in the $\mathrm{H}_{2} \mathrm{O} / \mathrm{LiX}$ mole ratio fits a linear function with an $R^{2}$ of $\geq 0.99$. The slope of the plots varies from $0.08 \pm 0.01 \mathrm{H}_{2} \mathrm{O} / \mathrm{LiX}$ mole ratio per humidity. In fact, this is not a small amount of water in the mesophase; for instance, in the $\mathrm{LiNO}_{3}$ sample, the change, from $10 \%$ to $33 \%$ humidity, is from $1.49 \mathrm{H}_{2} \mathrm{O} / \mathrm{LiNO}_{3}$ to $3.28 \mathrm{H}_{2} \mathrm{O} / \mathrm{LiNO}_{3}$ (it is 2.2 times or an increase from 7.5 to 16.4 in the $\mathrm{H}_{2} \mathrm{O} / \mathrm{C}_{12} \mathrm{E}_{10}$ mole ratio). It is similar in $\mathrm{LiCl}$ and $\mathrm{LiBr}$ samples, in which the amount of water increases by 1.7 and 1.6 times, respectively. Therefore, the fluctuation of the 
Table 1. $\mathrm{H}_{2} \mathrm{O} / \mathrm{LiX}$ Mole Ratios in the $n \mathrm{LiX} / \mathrm{C}_{12} \mathrm{E}_{10} / m \mathrm{H}_{2} \mathrm{O}$ LLC Mesophase $\left(\mathrm{X}^{-}\right.$is $\mathrm{Cl}^{-}, \mathrm{Br} \mathrm{NO}_{3}^{-}$, or $\mathrm{SCN}^{-}$, and $m$ is $n$ times the $\mathrm{H}_{2} \mathrm{O} / \mathrm{LiX}$ mole ratio), Calculated from Gravimetry Data

\begin{tabular}{|c|c|c|c|c|c|c|c|c|}
\hline \multirow[b]{2}{*}{ Salt $/ \mathrm{C}_{12} \mathrm{E}_{10}$ ratio $(n)$} & \multicolumn{2}{|c|}{$\mathrm{LiCl}$} & \multicolumn{2}{|c|}{$\mathrm{LiBr}$} & \multicolumn{2}{|c|}{$\mathrm{LiNO}_{3}$} & \multicolumn{2}{|c|}{ LiSCN } \\
\hline & 1 day & 4 days & 1 day & 4 days & 1 day & 4 days & 1 day & 4 days \\
\hline 1.3 & - & - & - & - & - & - & 2.1 & 1.7 \\
\hline 2 & 4.49 & 3.63 & 3.69 & 2.73 & 1.99 & 1.58 & $2.0^{a}$ & $1.6^{a}$ \\
\hline 3 & 3.69 & 5.75 & 3.68 & 3.10 & 1.52 & 1.32 & $2.0^{b}$ & $1.5^{b}$ \\
\hline 4 & 4.11 & 3.17 & 3.49 & 2.78 & 1.99 & 1.45 & 1.9 & 1.6 \\
\hline 5 & 4.40 & 3.84 & 4.25 & 3.97 & 2.37 & 2.04 & 2.0 & 1.9 \\
\hline 6 & 3.08 & 3.81 & 5.23 & 6.27 & 1.89 & 2.08 & 2.2 & 2.1 \\
\hline 7 & 3.96 & 3.91 & 3.74 & 3.90 & 2.08 & 2.05 & 2.3 & 2.2 \\
\hline 8 & 4.02 & 3.84 & 4.03 & 3.93 & 2.40 & 2.05 & 2.4 & 2.4 \\
\hline 9 & 4.52 & 4.08 & 4.43 & 3.98 & 1.42 & 2.05 & 2.6 & 2.5 \\
\hline 10 & 4.32 & 3.83 & 4.33 & 4.27 & 2.38 & 2.19 & 2.7 & 2.5 \\
\hline
\end{tabular}

${ }^{a} \mathrm{LiSCN} / \mathrm{C}_{12} \mathrm{E}_{10}$ mole ratio of $1.9 .{ }^{b} \mathrm{LiSCN} / \mathrm{C}_{12} \mathrm{E}_{10}$ mole ratio of 2 .
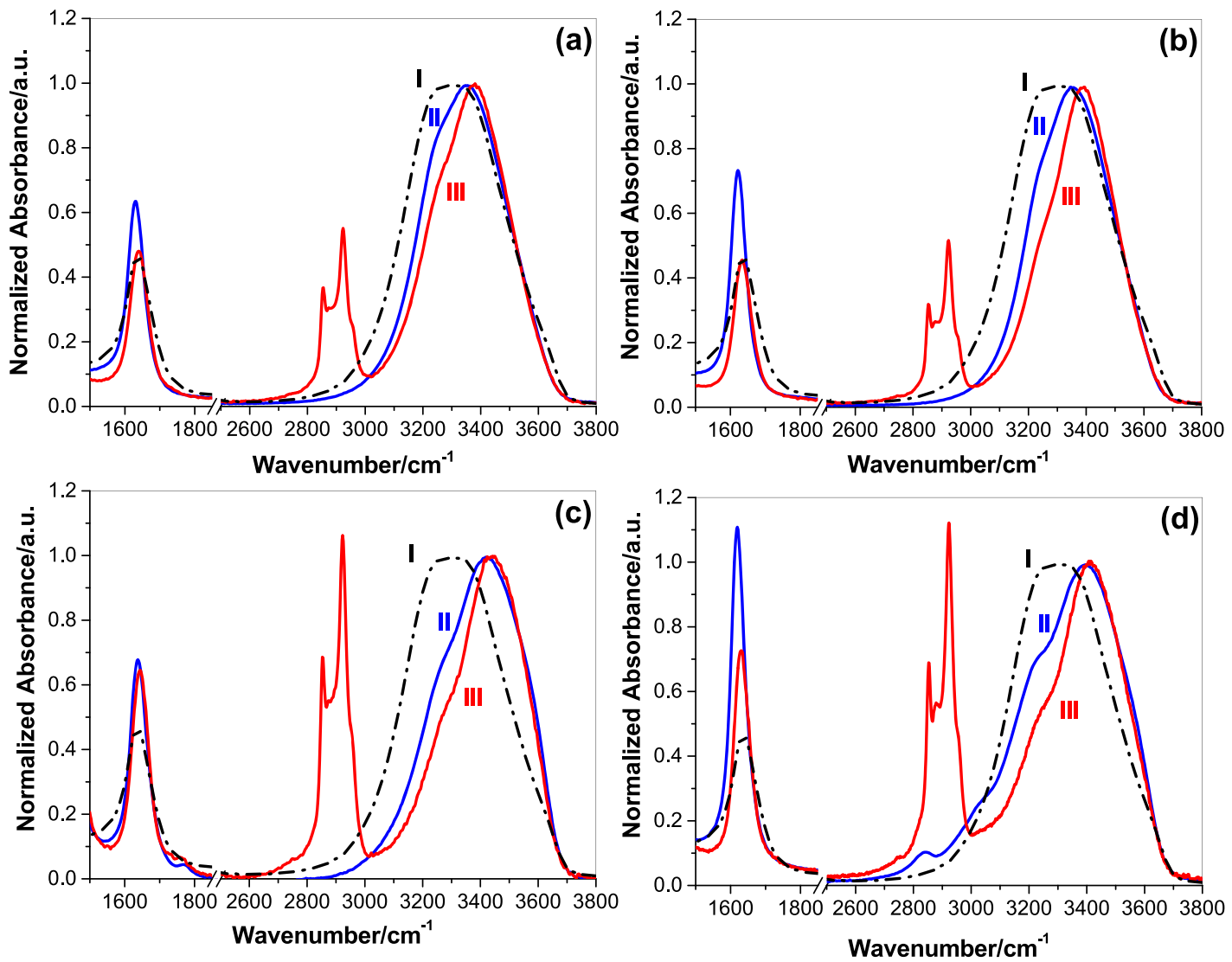

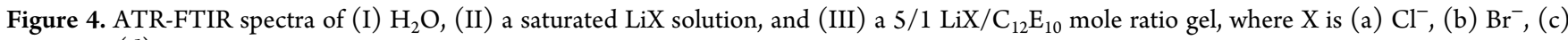
$\mathrm{NO}_{3}^{-}$, or (d) $\mathrm{SCN}^{-}$.

$\mathrm{H}_{2} \mathrm{O} / \mathrm{LiX}$ mole ratios in Table 1 is due to the mildly changing humidity level of the laboratory.

In another set of experiments, we employed ATR-FTIR spectroscopy to investigate the spectral changes and water removal process in the $\mathrm{LiX} / \mathrm{C}_{12} \mathrm{E}_{10} / \mathrm{H}_{2} \mathrm{O}$ systems. In Figure 4, the water bending and stretching spectral regions are plotted in four panels for the samples containing $\mathrm{LiCl}, \mathrm{LiBr}, \mathrm{LiNO}_{3}$, and LiSCN as saturated aqueous solutions and as LLC mesophases together with neat water. It was clear for all spectra that as the relative salt concentration increases the intensity of the water spectra decreases primarily from its ice-like (tetrahedral $\mathrm{H}$ bonded) water signal around $3200 \mathrm{~cm}^{-1}$. Moreover, the band due to more weakly interacting water (water-like) assigned to around $3400 \mathrm{~cm}^{-1}$ blue-shifts. When we move from the saturated salt solutions to gel LLC mesophases of these salts, the effect of the salt on water is clearly enhanced. Namely, the intensity of the $3200 \mathrm{~cm}^{-1}$ band decreases further and the water stretching band blue-shifts even further. The blue-shift in the $\mathrm{O}-\mathrm{H}$ stretching band is generally attributed to weaker $\mathrm{H}$ bonds in aqueous solutions and interfacial water molecules. ${ }^{54}$ It was also shown that weaker $\mathrm{H}$-bonds should yield a red-shift in the $\mathrm{H}-\mathrm{O}-\mathrm{H}$ bending mode. ${ }^{54,60,61}$ In sharp contrast in the LLC mesophase, it is difficult to form a direct analogy to known aqueous phase systems simply due to very small water/ salt mole ratios formed by the stable LLC mesophases (as low as 2). As such, the major contribution to the spectral changes 
here should be the lack of the H-bonding network of water (partially eliminated intermolecular coupling) as well as structural water, trapped between the ions and surfactants, and in the hydrations. These water spectra clearly indicate that the LLC phase contains salt/water mixtures, which has an even higher salt ion concentration, and thus, it contains water molecules that are more distorted compared to saturated salt solutions.

Moreover, ATR-FTIR spectroscopy can also be applied to monitor the entire water removal process. A drop of the sample solution with known initial compositions was placed on the ATR diamond crystal, and the spectra were recorded as a function of time. Figures S5-S9 show a set of row spectra of the $5 \mathrm{LiX} / \mathrm{C}_{12} \mathrm{E}_{10} / \mathrm{H}_{2} \mathrm{O}$ system during evaporation of water and a set of normalized spectra of the $5 \mathrm{LiBr} / \mathrm{C}_{12} \mathrm{E}_{10} / \mathrm{H}_{2} \mathrm{O}$ system. One must be careful how to evaluate this set of data to understand the observed changes (see the Supporting Information under ATR-FTIR). Comparing the raw ATRFTIR spectra of a sample, which undergoes multiple changes over time by changing its concentration and/or refractive index, can be misleading. This work is an excellent example for such samples (increases in both concentration and refractive index). Therefore, we normalized the time-dependent data using surfactant signals, the $\left(\nu_{\mathrm{as}}-\mathrm{CH}_{2}\right)$ peak at $2923 \mathrm{~cm}^{-1}$. Namely, we used the surfactant as an internal reference in the sample and report our results per surfactant (see the Supporting Information for details). Because the gel has the highest refractive index and concentration, it has the highest absorbance. The spectrum of the gel, recorded after the complete evaporation of water, is used to evaluate the normalization constants of each spectrum recorded during the evaporation of water. In other words, the time-dependent spectra are normalized to the spectrum of the sample after the evaporation of water reaches an equilibrium. The typical normalization constant of the first spectrum is around 6-8. The intensity of the normalized water peak decreases from 2.25 to 0.21 absorbance unit (see Figure S9). The intensity ratio is $\sim 10.5$ and consistent with the gravimetric data. Note that the $\mathrm{H}_{2} \mathrm{O} / \mathrm{LiBr}$ mole ratio is $\sim 35.2$ in the initial solution and decreases to 3-5 after the evaporationof water for $24 \mathrm{~h}$, depending on the percent humidity level of the laboratory for the $5 \mathrm{LiBr}$ sample.

Figure 5 shows the difference spectra, obtained from the normalized spectra, and displays the time-dependent spectral changes [in three different time domains during the evaporation of water from the $\mathrm{LiCl} / \mathrm{C}_{12} \mathrm{E}_{10} / \mathrm{H}_{2} \mathrm{O}(5 / 1 / 176)$ sample, like gravimetric data]. In the first region, the spectral changes show the evaporation of bulk water. This is evident because the spectral shape in this region is quite like that of bulk water. The spectral changes in the water stretching region change in the second region, indicating a change in the type of water evaporating from the sample, and correspond to evaporation of bulk and water in the extended hydration shells (except the first hydration shell due to energy considerations). In the third region, the spectral changes correspond to evaporation of hydration water. All three peak maxima due to water stretching, bending, and libration modes blue-shift from one region to the next (see Figure 5). As the $\mathrm{O}-\mathrm{H}$ bond strengthens, the stretching bands blue-shift and the strength of hydrogen bonding becomes weaker among the hydration water molecules in the mesophase. All other $\mathrm{LiX} /$ $\mathrm{C}_{12} \mathrm{E}_{10} / \mathrm{H}_{2} \mathrm{O}\left(\mathrm{X}\right.$ is $\mathrm{Cl}^{-}, \mathrm{Br}^{-}, \mathrm{NO}_{3}^{-}$, and $\mathrm{SCN}^{-}$) samples, at $\mathrm{LiX} / \mathrm{C}_{12} \mathrm{E}_{10}$ mole ratios from 2 to 10 , were also followed
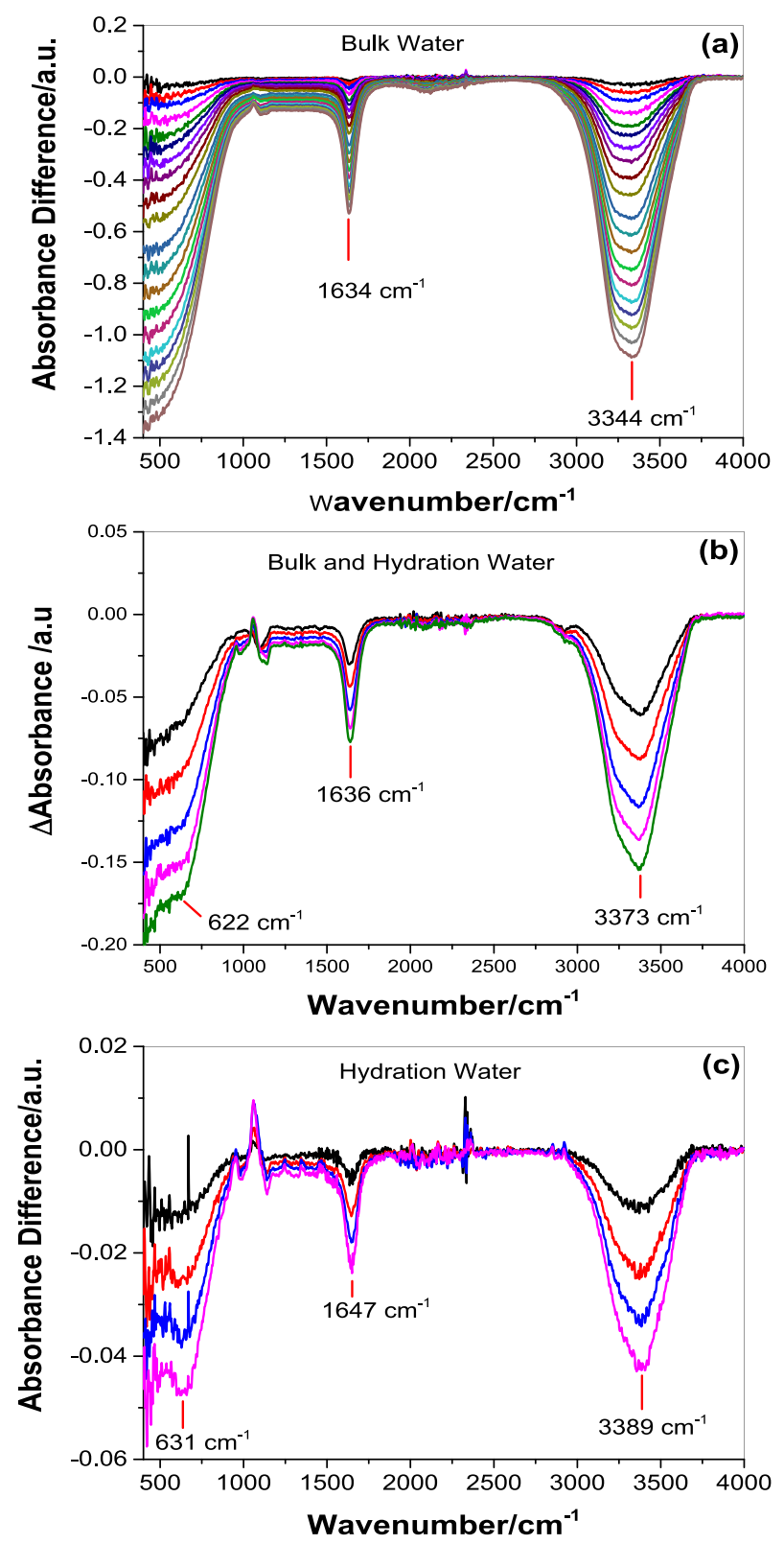

Figure 5. Difference spectra of the normalized ATR-FTIR spectra, recorded during the evaporation of water from the $5 \mathrm{LiCl} / \mathrm{C}_{12} \mathrm{E}_{10} /$ $\mathrm{H}_{2} \mathrm{O}$ system (a) from a solution, (b) during gelation, and (c) from a gel.

spectroscopically (see Figures S10-S12), and similar trends were observed consisting of the same three regions.

Figure 6a shows the ATR-FTIR spectra of the LiSCN/ $\mathrm{C}_{12} \mathrm{E}_{10} / \mathrm{H}_{2} \mathrm{O}$ system at different $\mathrm{LiSCN} / \mathrm{C}_{12} \mathrm{EO}_{10}$ mole ratios. As gravimetrically determined in the LiSCN samples, the $\mathrm{H}_{2} \mathrm{O} / \mathrm{LiSCN}$ ratio gradually increases above $5 \mathrm{LiSCN} / \mathrm{C}_{12} \mathrm{E}_{10}$ mole ratio samples. Because of the surfactant $\left(\nu_{\mathrm{as}}-\mathrm{CH}_{2}\right)$ peak at $2923 \mathrm{~cm}^{-1}$, used as a reference for normalization of the spectra, the intensity of water peak maxima $\left(I_{\mathrm{W}}\right)$ can be divided by the surfactant peak intensity $\left(I_{\mathrm{S}}\right)$ to normalize the spectra of each $\mathrm{LiX}$ sample at different mole ratios. Figure $6 \mathrm{~b}$ shows the plots of $I_{\mathrm{W}} / I_{\mathrm{S}}$ versus $\mathrm{LiX} / \mathrm{C}_{12} \mathrm{E}_{10}$ mole ratios. Each plot fits a linear relationship ( $R^{2}$ varies from 0.95 to 0.99 ) with a different slope; the values are $0.41,0.40,0.27$, and 0.17 for $\mathrm{LiCl}, \mathrm{LiBr}$, $\mathrm{LiSCN}$, and $\mathrm{LiNO}_{3}$, respectively (see Figure 6). This trend is consistent with the gravimetric data. 

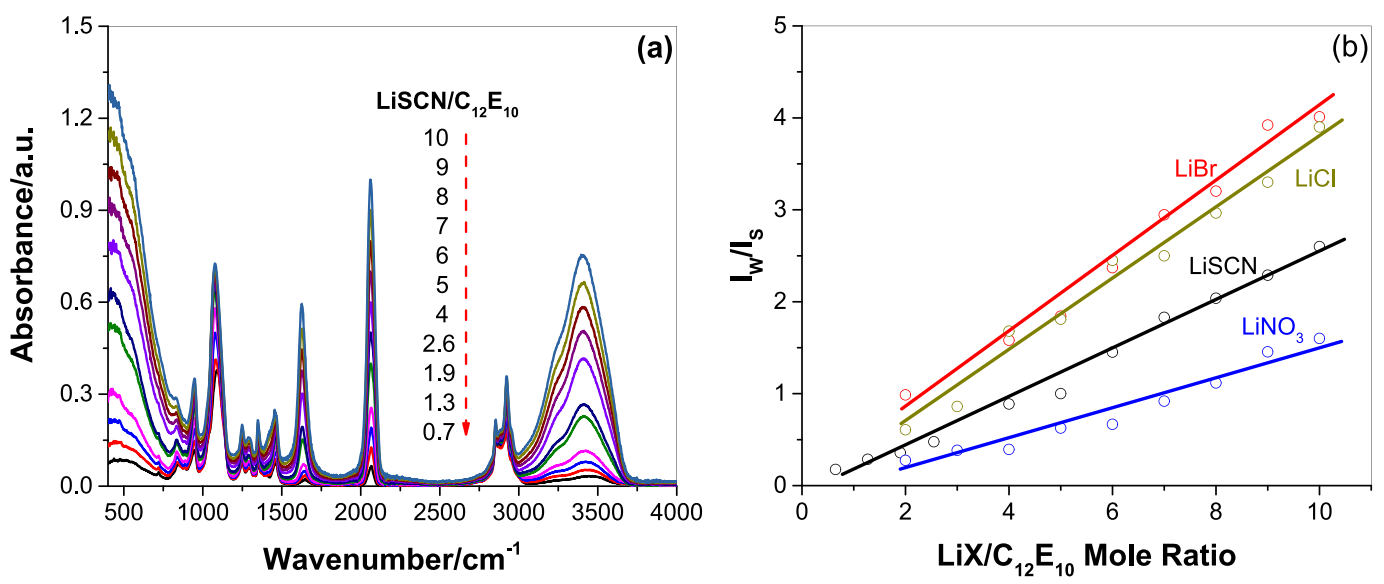

Figure 6. (a) ATR-FTIR spectra of LiSCN $/ \mathrm{C}_{12} \mathrm{E}_{10} / \mathrm{H}_{2} \mathrm{O}$ mesophases at LiSCN/C $\mathrm{C}_{12} \mathrm{E}_{10}$ mole ratios from 1.3 to 10 and (b) plot of $I_{\mathrm{W}} / I_{\mathrm{S}}$ vs LiX/ $\mathrm{C}_{12} \mathrm{E}_{10}$ mole ratio (fits to a linear equation) of all LLC phases.
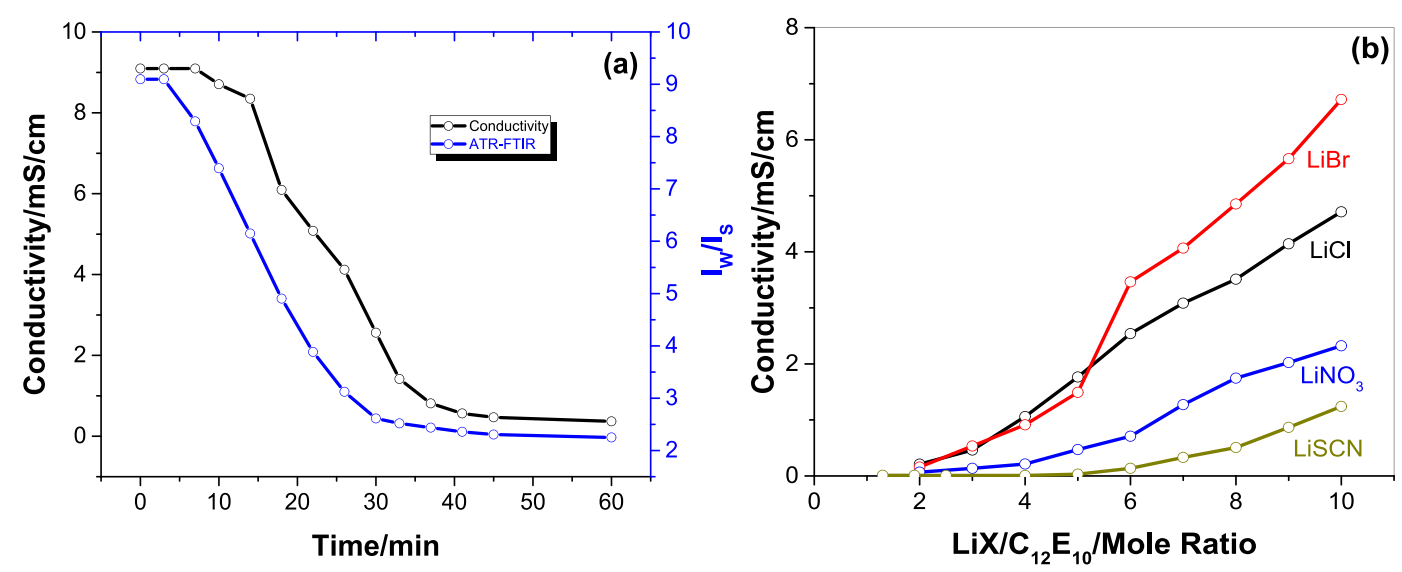

Figure 7. (a) Plots of conductivity vs time and $I_{\mathrm{W}} / I_{\mathrm{S}}$ ratio vs time of the $5 \mathrm{LiBr}$ sample and (b) plots of conductivity vs LiX/C $\mathrm{C}_{12} \mathrm{E}_{10}$ mole ratio of $\mathrm{LiX} / \mathrm{C}_{12} \mathrm{E}_{10} / \mathrm{H}_{2} \mathrm{O}$ mesophases $\left[\mathrm{X}\right.$ is $\mathrm{Cl}^{-}$(black), $\mathrm{Br}^{-}$(red), $\mathrm{NO}_{3}^{-}$(blue), and $\mathrm{SCN}^{-}$(dark yellow)]. Symbols show data points, and lines only connect the data points.

The evaporation of water was also monitored using conductivity measurements. The conductivity was measured using a homemade cell using FTO glass (see the Experimental Section for details). The plot of conductivity versus time closely follows the $I_{\mathrm{W}} / I_{\mathrm{S}}$ in the ATR-FTIR spectroscopic data (see Figure $7 \mathrm{a}$ ). The conductivity plot can also be divided into three regions, solution phase, gelation, and evaporation of excess water in the gel phase. The conductivity slowly decays as water evaporates from the solution phase (see Figure 7a). This is consistent with the formation of ion pairs and the decay in the mobility of free ions in the solution with an increase in the viscosity of the media together with mesophase formation. The decrease in conductivity is sharper during gelation and further decreases in the gel phase. Figure $7 \mathrm{~b}$ shows the variation in conductivity with an increase in the level of $\mathrm{LiX}$ in the $\mathrm{LiX} / \mathrm{C}_{12} \mathrm{E}_{10} / \mathrm{H}_{2} \mathrm{O}$ mesophases. It is also important to notice that the amount of water in the mesophase is more dominant in the conductivity values. With complete evaporation of water under a constant humidity, the conductivity gradually increases with an increasing salt/surfactant ratio in the following order: $\sigma_{\mathrm{LiCl}}>\sigma_{\mathrm{LiBr}}>\sigma_{\mathrm{LiNO}_{3}}>\sigma_{\mathrm{LiSCN}}$. However, the order changes at a salt/surfactant ratio of 5: $\sigma_{\mathrm{LiBr}}>\sigma_{\mathrm{LiCl}}>$ $\sigma_{\mathrm{LiNO}_{3}}>\sigma_{\mathrm{LiSCN}}$. There is a sharp increase in the conductivity of $6 \mathrm{LiBr}$, due to a change in the mesostructure. Indeed, the $\mathrm{LiBr}$ / $\mathrm{C}_{12} \mathrm{E}_{10} / \mathrm{H}_{2} \mathrm{O}$ mesophase transforms from hexagonal to cubic at around the same mole ratio. A similar behavior exists in other LLC phases in which the phase transformation from hexagonal to cubic enhances the conductivity. ${ }^{62}$

The ATR-FTIR technique was also employed to check the response of the humidity of the samples using a homemade setup that provides a constant humidity using saturated salt solutions. A drop of the $\mathrm{LiX} / \mathrm{C}_{12} \mathrm{E}_{10} / \mathrm{H}_{2} \mathrm{O}$ solution was placed over the ATR crystal and aged for gelation (until it reaches an equilibrium, aged for $24 \mathrm{~h}$ ); then the saturated salt solution was placed next to the sample in a vial, and the sample and saturated salt solution together were sealed with a plastic container to ensure a well-sealed atmosphere with a constant volume. Then, the spectrum of the sample was recorded after it had aged for an additional $24 \mathrm{~h}$ to ensure the sample reaches a new equilibrium under the new humidity conditions. This test was repeated using the atmosphere of each saturated solution (LiCl, $\mathrm{MgCl}_{2}, \mathrm{~K}_{2} \mathrm{CO}_{3}, \mathrm{NaBr}, \mathrm{KI}, \mathrm{NaCl}$, and $\mathrm{KCl}$ salts that ensure $11 \%, 33 \%, 43 \%, 57 \%, 68 \%, 75 \%$, and $85 \%$ humidity, respectively). Figure $8 \mathrm{a}$ shows the water stretching region of the normalized ATR-FTIR spectra of the $5 \mathrm{LiCl}$ sample. The inset of Figure $8 \mathrm{a}$ is the plot of $I_{\mathrm{W}} / I_{\mathrm{S}}$ that follows a linear dependence and only positively deviates at low humidity. However, the amount of water in the sample gradually increases by 3 times going from $11 \%$ to $85 \%$ humidity. The same sample was checked to determine whether the 

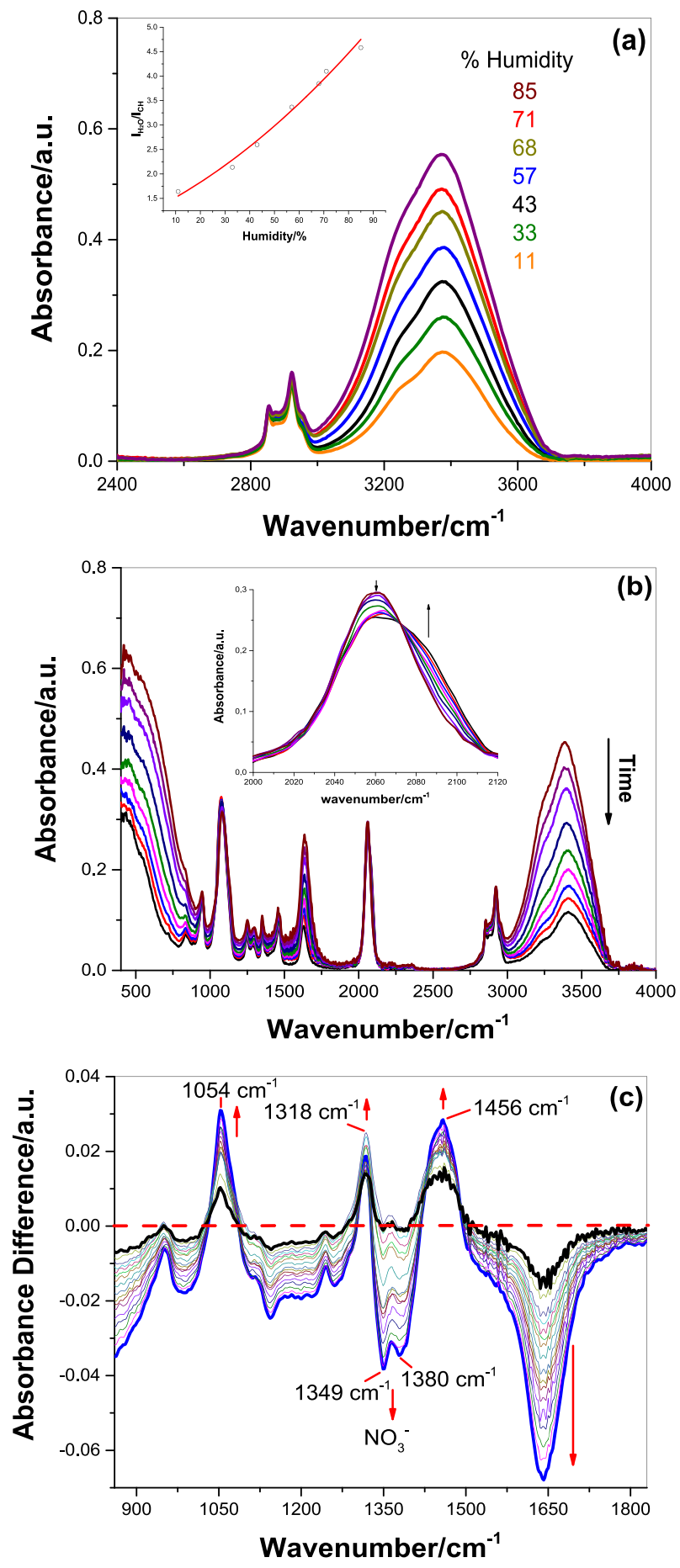

Figure 8. ATR-FTIR spectra of (a) the $5 \mathrm{LiCl} / \mathrm{C}_{12} \mathrm{E}_{10} / \mathrm{H}_{2} \mathrm{O}$ mesophase at various percent humidities (the inset is the plot of $I_{\mathrm{W}} / I_{\mathrm{S}}$ vs humidity, fitted to an exponential function), (b) the third region of the $5 \mathrm{LiSCN} / \mathrm{C}_{12} \mathrm{E}_{10} / \mathrm{H}_{2} \mathrm{O}$ system $(5-24 \mathrm{~h}$ period of evaporation of water; the inset is the $\nu$ - $\mathrm{CN}$ region), and (c) difference spectra in the third region of the $5 \mathrm{LiNO}_{3} / \mathrm{C}_{12} \mathrm{E}_{10} / \mathrm{H}_{2} \mathrm{O}$ system.

mesophase is still stable or not with such large amounts of water by keeping it in a humidity chamber, prior to gelation, at $75 \%$ humidity for $24 \mathrm{~h}$. Then it is sealed in the humidity chamber with a cover glass to keep the water in the sample for inspection under POM. The POM image displays birefringent texture, indicating that the mesophase is still stable under such high humidity (see Figure S13). The humidity-dependent conductivity measurements were also carried at three different humidity levels using the same setup, and as expected, the conductivity gradually increases with the humidity of the atmosphere (see Table S5).

The time-dependent spectroscopic data (during the evaporation of water) were recorded for all salt systems and all compositions. Figure $8 \mathrm{~b}$ shows a set of spectra collected from the $5 \mathrm{LiSCN}$ sample after it had aged for $5 \mathrm{~h}$ over the ATR crystal until $24 \mathrm{~h}$. The $I_{\mathrm{W}} / I_{\mathrm{S}}$ ratio decreases from 11.94 to 3.44 in the first $5 \mathrm{~h}$ and further decreases to 0.87 in $24 \mathrm{~h}$. After the sample had been aged for $24 \mathrm{~h}$, its composition was $5 / 1 / 10$ $\mathrm{LiSCN} / \mathrm{C}_{12} \mathrm{E}_{10} / \mathrm{H}_{2} \mathrm{O}$, with two waters per LiSCN. Note also that the spectra display features similar to those recorded under around $75 \%$ to $17 \%$ humidity, at which the LLC gel phase is stable. This region also corresponds to the third region in the gravimetric data. The inset of Figure $8 \mathrm{~b}$ shows the $\nu$-CN stretching region of the same spectra. Notice that the $\nu$-CN region is observed around $2060 \mathrm{~cm}^{-1}$, but at such a high salt concentration, the $\mathrm{SCN}^{-}$ions cannot remain as free ions; it instead forms ion pairs $(\mathrm{Li}-\mathrm{SCN})$ and dimers $\left[\mathrm{Li}_{2}(\mathrm{SCN})_{2}\right]$, which appear at 2081 and $2045 \mathrm{~cm}^{-1}$, respectively, in the spectrum. ${ }^{63,64}$ Clearly, different ionic species (free ion, ion pair, and dimer) coexist in the mesophase even in the solution phase. With the evaporation of water, specifically in the third region, the intensity of the ion-pair band (at $\sim 2081 \mathrm{~cm}^{-1}$ ) gradually increases at the expense of that of the free ion $\left(\sim 2060 \mathrm{~cm}^{-1}\right)$ (see the inset of Figure $8 \mathrm{~b}$ ). Unlike the spectra of $\mathrm{LiBr} / \mathrm{C}_{12} \mathrm{E}_{10} / \mathrm{H}_{2} \mathrm{O}$ and $\mathrm{LiCl} / \mathrm{C}_{12} \mathrm{E}_{10} / \mathrm{H}_{2} \mathrm{O}$ samples, the spectra of both $\mathrm{LiSCN} / \mathrm{C}_{12} \mathrm{E}_{10} / \mathrm{H}_{2} \mathrm{O}$ and $\mathrm{LiNO}_{3} / \mathrm{C}_{12} \mathrm{E}_{10} /$ $\mathrm{H}_{2} \mathrm{O}$ samples display features related to $\mathrm{SCN}^{-}$and $\mathrm{NO}_{3}{ }^{-}$ ions, respectively. Like $\mathrm{SCN}^{-}$ions, the $\mathrm{NO}_{3}{ }^{-}$ions also display features related to the ion pair and dimers. The free nitrate ion appears at $1350 \mathrm{~cm}^{-1}$ as a single peak due to doubly degenerate asymmetric stretching modes $\left(\nu_{\mathrm{as}}-\mathrm{NO}_{3}\right)$ in a dilute solution phase. However, even in the solution phase of our samples, the $\nu_{\text {as }}-\mathrm{NO}_{3}$ mode weakly splits into two due to strong and weak interaction with water; ${ }^{65}$ however, with further evaporation of water, the splitting becomes large, indicating stronger interactions with the $\mathrm{Li}^{+}$ion as an ion pair and dimer. Figure $8 \mathrm{c}$ displays difference spectra toward the end of the evaporation of water (third region). The intensities of the ion-pair and dimer-related peaks, observed at 1318 and $1456 \mathrm{~cm}^{-1}$, respectively, increase, and the peak intensity of the free nitrate, interacting with water, declines upon further evaporation of water in the $5 \mathrm{LiNO}_{3} / \mathrm{C}_{12} \mathrm{E}_{10} / \mathrm{H}_{2} \mathrm{O}$ mesophase, like in the case of $\mathrm{SCN}^{-}$ions. The inactive symmetric stretching mode of the nitrate ion also appears as a peak around $1054 \mathrm{~cm}^{-1}$ due to the interactions mentioned above (see Figure $8 \mathrm{c}$ ). The other features around $1100 \mathrm{~cm}^{-1}$ could be due to interaction, and a red-shift of the $\mathrm{C}-\mathrm{O}$-related peaks of the surfactant indicates that the $\mathrm{LiNO}_{3}$ species are also interacting with the ethylene oxide sides of surfactant domains in the mesophase.

Overall, the ATR-FTIR spectroscopic data correlate with the gravimetry data. Figure 9 shows normalized ATR-FTIR spectra of all of the samples with $\mathrm{LiX} / \mathrm{C}_{12} \mathrm{E}_{10}$ mole ratios of 5 after the evaporation of water and the stable mesophase form. As already determined from the gravimetric data, the amount of water kept in the mesophase decreases in the following order: $\mathrm{LiCl}>\mathrm{LiBr}>\mathrm{LiSCN}>\mathrm{LiNO}_{3}$. The water stretching peak maxima also follow the same trend; the peak maxima are observed at $3377,3388,3410$, and $3444 \mathrm{~cm}^{-1}$, respectively. The weakly $\mathrm{H}$-bonded water molecules in the sample are 

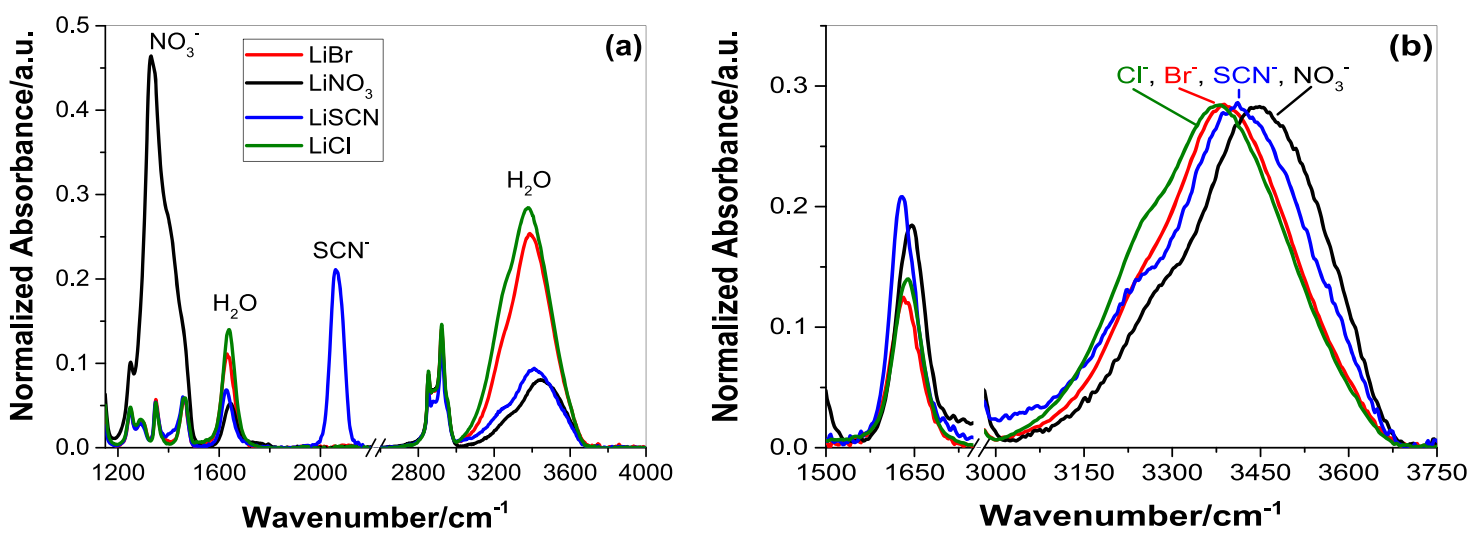

Figure 9. ATR-FTIR spectra of the $5 \mathrm{LiX} / \mathrm{C}_{12} \mathrm{E}_{10} / \mathrm{H}_{2} \mathrm{O}$ system $\left(\mathrm{X}\right.$ is $\mathrm{Cl}^{-}, \mathrm{Br}^{-}, \mathrm{SCN}^{-}$, or $\left.\mathrm{NO}_{3}^{-}\right)$after the complete evaporation of water (a) normalized to surfactant peaks and (b) normalized to the water peak.

present among the salt ions and between the ions and surfactant ethylene oxide domains. More importantly, the remaining water in the sample is the hydration water around the ions. For more weakly hydrated anions $\left(\mathrm{SCN}^{-}\right.$and $\left.\mathrm{NO}_{3}{ }^{-}\right)$, a small amount of water is necessary to maintain the stability of the mesophase. The required amount increases with monatomic anions. To gain more in-depth information, we also normalized all of the water stretching peak maxima (see Figure $9 \mathrm{~b}$ ) and compared the water bending modes. The bending region displays interesting behaviors. First, the frequency of the bending mode follows quite a different order, $\delta_{\mathrm{LiNO}_{3}}>\delta_{\mathrm{LiCl}}>\delta_{\mathrm{LiBr}}>\delta_{\mathrm{LiSCN}}$, with an intensity order of $\mathrm{I}_{\mathrm{LiSCN}}>\mathrm{I}_{\mathrm{LiNO}_{3}}>\mathrm{I}_{\mathrm{LiCl}}>\mathrm{I}_{\mathrm{LiBr}}$. The peak position and intensity orders together show that the molecular level picture is complex. Although the stretching band positions show H-bond weakening in the samples, the bending mode does not support this notion with the expected red-shifted peak positions. This should be due to the structurally broken $\mathrm{H}$-bond network of water.

Surprisingly, the ion specific effects shown in this study do not exactly follow the anionic Hofmeister series. However, the intensity ratios of the water stretching to bending bands phenomenologically follow the Hofmeister series. The ratios are 1.37, 1.64, 2.03, and 2.33 for $\mathrm{LiSCN}, \mathrm{LiNO}_{3}, \mathrm{LiBr}$, and $\mathrm{LiCl}$, respectively. The concepts of "structure makers" and "structure breakers" have lost their impact for aqueous solutions. For the water-starved systems, as we have shown for the LLC mesophases, the specific ion effects still hold the traditional view of structure makers and breakers of the $\mathrm{H}$ bond network.

\section{CONCLUSION}

Lithium salts ( $\mathrm{LiX}$ ) and oligo(ethylene oxide) type surfactants, namely 10 lauryl ether, form lyotropic liquid crystalline mesophases in the presence of water in a broad range of salt amounts $\left(\mathrm{LiX} / \mathrm{C}_{12} \mathrm{E}_{10}\right.$ mole ratios of 1.3-10). Here, four lithium salts $\left(\mathrm{LiCl}, \mathrm{LiBr}, \mathrm{LiNO}_{3}\right.$, and $\left.\mathrm{LiSCN}\right)$ were used to investigate the role of water that is required for mesophase formation. Aqueous solutions of $\mathrm{LiX}$ and $\mathrm{C}_{12} \mathrm{E}_{10}$ lose their excess water to form their LLC mesophases. The amount of water that remains in the mesophase depends on the salt and humidity. Typically, the $\mathrm{H}_{2} \mathrm{O} / \mathrm{LiX}$ ratio is around 4 for $\mathrm{LiCl}$ and $\mathrm{LiBr}$ mesophases but as low as 2 for LiSCN and 1.5 for $\mathrm{LiNO}_{3}$ at around $20 \%$ humidity; it increases with humidity by $0.08 \mathrm{H}_{2} \mathrm{O}$ per humidity. Mesophases are also stable in a broad range of humdities (10-85\% humidity; values outside of this range are not measured in this work). Evaporation of water from these solutions can be monitored by gravimetric, spectroscopic, and conductivity techniques. All methods show that there are three different evaporation regions in which the kinetics of evaporation of water are different. In the first region, evaporation of bulk water is observed from a highly saturated solution phase. In the second region, evaporation leads to the formation of the LLC mesophase (gelation, evaporation of bulk water, and likely the extended hydration spheres), where the evaporation slows. The last region is the release of water from the LLC mesophase, which is the slowest step. Typically, evaporation reaches completion in $24 \mathrm{~h}$. The same process can be followed using ATR-FTIR spectroscopy. However, the spectra must be normalized to follow timedependent changes during the evaporation of water. Normalization can be performed by either using the intensity of the surfactant $\mathrm{C}-\mathrm{H}$ stretching bands or taking the change in $\mathrm{LiX}$ concentration into account (for instance, in the $5 \mathrm{LiCl}$ sample, the $\mathrm{LiCl}$ concentration changes from 1.6 to $11 \mathrm{M}$ ). Both water stretching and bending modes sense the $\mathrm{X}^{-}$ions in the mesophase and can be put into an order. The stretching frequecy order of the four salts is as follows: $\nu_{\mathrm{LiCl}}<\nu_{\mathrm{LiBr}}<$ $\nu_{\mathrm{LiSCN}}<\nu_{\mathrm{LiNO}_{3}}$ (related to hydrogen-bonding and ion-water interaction). The bending mode frequency and intensity also respond to the $\mathrm{X}^{-}$ion type. The frequecy decreases in the following order: $\delta_{\mathrm{LiNO}_{3}}>\delta_{\mathrm{LiCl}}>\delta_{\mathrm{LiBr}}>\delta_{\mathrm{LiSCN}}$. The intensity decreases in the following order: $I_{\mathrm{LiSCN}}>I_{\mathrm{LiNO}_{3}}>I_{\mathrm{LiCl}}>I_{\mathrm{LiBr}}$. The order of ionic conductivity of the mesophases is as follows at a $\mathrm{LiX} / \mathrm{C}_{12} \mathrm{E}_{10}$ mole ratio of $<6: \sigma_{\mathrm{LiCl}}>\sigma_{\mathrm{LiBr}}>\sigma_{\mathrm{LiNO}_{3}}>\sigma_{\mathrm{LiSCN}}$. The order is as follows due to a structural change in the mesophase: $\sigma_{\mathrm{LiBr}}>\sigma_{\mathrm{LiCl}}>\sigma_{\mathrm{LiNO}_{3}}>\sigma_{\mathrm{LiSCN}}$. The $\mathrm{LiBr} / \mathrm{C}_{12} \mathrm{E}_{10} /$ $\mathrm{H}_{2} \mathrm{O}$ mesophase is cubic at $\mathrm{LiBr} / \mathrm{C}_{12} \mathrm{E}_{10}$ mole ratios of $\geq 6$. The conductivity data can also be correlated with the spectroscopic data, showing that this order is related to the formation of an ion pair and dimerization and ion-surfactant interactions.

The methods employed in this work are unique for exploring the role of water and ions in the structure, mesophase stability, and assembly of LLC mesophases. Further investigations in other systems, such as acid/surfactant and transition metal salt/surfactant mesophases, may be performed to contribute to the discussion of specific ion effects from concentrated systems that have not yet been investigated. 


\section{ASSOCIATED CONTENT}

\section{s) Supporting Information}

The Supporting Information is available free of charge at https://pubs.acs.org/doi/10.1021/acs.langmuir.1c02411.

ATR-FTIR principles, tables of compositions, small angle XRD patterns of the $\mathrm{LiSCN} / \mathrm{C}_{12} \mathrm{E}_{10} / \mathrm{H}_{2} \mathrm{O}$ system, additional gravimetric data for the $\mathrm{LiX} / \mathrm{C}_{12} \mathrm{E}_{10} / \mathrm{H}_{2} \mathrm{O}$ systems ( $\mathrm{X}$ is $\mathrm{Br}^{-}, \mathrm{NO}_{3}{ }^{-}$, or $\mathrm{SCN}^{-}$), time-dependent ATR-FTIR spectra of the $\mathrm{LiX} / \mathrm{C}_{12} \mathrm{E}_{10} / \mathrm{H}_{2} \mathrm{O}$ systems (X is $\mathrm{Cl}^{-}, \mathrm{Br}^{-}, \mathrm{NO}_{3}^{-}$, or $\left.\mathrm{SCN}^{-}\right)$, normalized ATR-FTIR spectra of the $\mathrm{LiX} / \mathrm{C}_{12} \mathrm{E}_{10} / \mathrm{H}_{2} \mathrm{O}$ systems $\left(\mathrm{X}\right.$ is $\mathrm{Cl}^{-}, \mathrm{Br}^{-}$, $\mathrm{NO}_{3}{ }^{-}$, or $\mathrm{SCN}^{-}$), and humidity-dependent POM images of the $\mathrm{LiNO}_{3} / \mathrm{C}_{12} \mathrm{E}_{10} / \mathrm{H}_{2} \mathrm{O}$ system (PDF)

\section{AUTHOR INFORMATION}

\section{Corresponding Author}

Ömer Dag - Department of Chemistry and UNAM-National Nanotechnology Research Center and Institute of Materials Science and Nanotechnology, Bilkent University, 06800 Ankara, Turkey; 이이이.org/0000-0002-1129-3246; Email: dag@fen.bilkent.edu.tr

\section{Authors}

Ezgi Yılmaz Topuzlu - Department of Chemistry, Bilkent University, 06800 Ankara, Turkey

Halil I. Okur - Department of Chemistry and UNAMNational Nanotechnology Research Center and Institute of Materials Science and Nanotechnology, Bilkent University, 06800 Ankara, Turkey; 이이.org/0000-0002-2492-1168

Burak Ulgut - Department of Chemistry and UNAMNational Nanotechnology Research Center and Institute of Materials Science and Nanotechnology, Bilkent University, 06800 Ankara, Turkey; 이이.org/0000-0002-4402-0033

Complete contact information is available at:

https://pubs.acs.org/10.1021/acs.langmuir.1c02411

\section{Notes}

The authors declare no competing financial interest.

\section{ACKNOWLEDGMENTS}

The authors thank TÜBİTAK (under Project 118Z820) for the financial support of this work. Ö.D. is a member of the Science Academy, Istanbul, Turkey.

\section{REFERENCES}

(1) Chu, S.; Cui, Y.; Liu, N. The path towards sustainable energy. Nat. Mater. 2017, 16, 16-22.

(2) Xia, L.; Yu, L.; Hu, D.; Chen, G. Z. Electrolytes for electrochemical energy storage. Mater. Chem. Front. 2017, 1, 584618.

(3) Zhong, C.; Deng, Y.; Hu, W.; Qiao, J.; Zhang, L.; Zhang, J. A review of electrolyte materials and compositions for electrochemical supercapacitors. Chem. Soc. Rev. 2015, 44, 7484-7539.

(4) $\mathrm{Xu}, \mathrm{K}$. Nonaqueous liquid electrolytes for lithium-based rechargeable batteries. Chem. Rev. 2004, 104, 4303-4418.

(5) Pan, L.; Yu, G.; Zhai, D.; Lee, H. R.; Zhao, W.; Liu, N.; Wang, H.; Tee, B. C.-K.; Shi, Y.; Cui, Y.; Bao, Z. Hierarchical nanostructured conducting polymer hydrogel with high electrochemical activity. Proc. Natl. Acad. Sci. U. S. A. 2012, 109, 9287-9292.

(6) Li, L.; Shi, Y.; Pan, L.; Shi, Y.; Yu, G. Rational design, and applications of conducting polymer hydrogels as electrochemical biosensors. J. Mater. Chem. B 2015, 3, 2920-2930.
(7) Zhao, Y.; Liu, B.; Pan, L.; Yu, G. 3D nanostructured conductive polymer hydrogels for high-performance electrochemical devices. Energy Environ. Sci. 2013, 6, 2856-2870.

(8) Ahmad, Z.; Hong, Z.; Viswanathan, V. Design rules for liquid crystalline electrolytes for enabling dendrite-free lithium metal batteries. Proc. Natl. Acad. Sci. U. S. A. 2020, 117, 26672-26680.

(9) Kato, T. From nanostructured liquid crystals to polymer-based electrolytes. Angew. Chem., Int. Ed. 2010, 49, 7847-7848.

(10) Imrie, C. T.; Ingram, M. D.; McHattie, G. S. Ion transport in glassy side-group liquid crystalline polymer electrolytes. Adv. Mater. 1999, 11, 832-834.

(11) Sakuda, J.; Hosono, E.; Yoshio, M.; Ichikawa, T.; Matsumoto, T.; Ohno, H.; Zhou, H.; Kato, T. Liquid-crystalline electrolytes for lithium-ion batteries: Ordered assemblies of a mesogen-containing carbonate and a lithium salt. Adv. Funct. Mater. 2015, 25, 1206-1212.

(12) Ichikawa, T.; Yoshio, M.; Hamasaki, A.; Kagimoto, J.; Ohno, H.; Kato, T. 3D interconnected ionic nano-channels formed in polymer films: self-organization and polymerization of thermotropic bicontinuous cubic liquid crystals. J. Am. Chem. Soc. 2011, 133, 21632169.

(13) Kerr, R. L.; Edwards, J. P.; Jones, S. C.; Elliott, B. J.; Gin, D. L. Effect of varying the composition and nanostructure of organic carbonate-containing lyotropic liquid crystal polymer electrolytes on their ionic conductivity. Polym. J. 2016, 48, 635-643.

(14) Kerr, R. L.; Miller, S. A.; Shoemaker, R. K.; Elliott, B. J.; Gin, D. $\mathrm{L}$. New type of $\mathrm{Li}$ ion conductor with $3 \mathrm{D}$ interconnected nanopores via polymerization of a liquid organic electrolyte-filled lyotropic liquid-crystal assembly. J. Am. Chem. Soc. 2009, 131, 15972-15973.

(15) Eisele, A.; Kyriakos, K.; Bhandary, R.; Schönhoff, M.; Papadakis, C. M.; Rieger, B. Structure and ionic conductivity of liquid crystals having propylene carbonate units. J. Mater. Chem. A 2015, 3, 2942-2953.

(16) Onuma, T.; Hosono, F.; Takenouchi, M.; Sakuda, J.; Kajiyama, S.; Yoshio, M.; Kato, T. Noncovalent approach to liquid-crystalline ion conductors: High-rate performances and room-temperature operation for Li-ion batteries. ACS Omega 2018, 3, 159-166.

(17) Zhang, G.; Chen, X.; Zhao, Y.; Ma, F.; Jing, B.; Qiu, H. Lyotropic liquid-crystalline phases formed by pluronic P123 in ethylammonium nitrate. J. Phys. Chem. B 2008, 112, 6578-6584.

(18) Wang, L.; Chen, X.; Chai, Y.; Hao, J.; Sui, Z.; Zhuang, W.; Sun, Z. Lyotropic liquid crystalline phases formed in an ionic liquid. Chem. Commun. 2004, 2840-2841.

(19) Tunkara, E.; Albayrak, C.; Polat, E. O.; Kocabas, C.; Dag, Ö. Highly proton conductive phosphoric acid-nonionic surfactant lyotropic liquid crystalline mesophases and application in graphene optical modulators. ACS Nano 2014, 8, 11007-11012.

(20) Albayrak, C.; Cihaner, A.; Dag, Ö. A new, highly conductive, lithium salt/nonionic surfactant, lyotropic liquid-crystalline mesophase and its application. Chem. - Eur. J. 2012, 18, 4190-4194.

(21) Balcı, F.; Balc1, S.; Kocabas, C.; Dag, Ö. Lyotropic liquidcrystalline mesophase of lithium triflate-nonionic surfactant as gel electrolyte for graphene optical modulator. J. Phys. Chem. C 2017, $121,11194-11200$.

(22) Yılmaz, E.; Olutaş, E. B.; Barım, G.; Bandara, J.; Dag, Ö. Lithium salt-nonionic surfactant lyotropic liquid crystalline gelelectrolytes with redox couple for dye sensitized solar cells. RSC Adv. 2016, 6, 97430-97437.

(23) Soni, S. S.; Fadadu, K. B.; Gibaud, A. Ionic conductivity through thermoresponsive polymer gel: ordering matters. Langmuir 2012, 28, 751-756.

(24) Salikolimi, K.; Sudhakar, A. A.; Ishida, Y. Functional ionic liquid crystals. Langmuir 2020, 36, 11702-11731.

(25) Saat, G.; Balcı, F. M.; Alsaç, E. P.; Karadas, F.; Dag, Ö. Molten salt self-assembly: synthesis of mesoporous $\mathrm{LiCoO}_{2}$ and $\mathrm{LiMn}_{2} \mathrm{O}_{4}$ thin films and investigation of electrocatalytic water oxidation performance of lithium cobaltate. Small 2018, 14, 1701913.

(26) Balci, F. M.; Karakaya, I.; Alsaç, E. P.; Yaman, M. Y.; Saat, G.; Karadas, F.; Ülgüt, B.; Dag, Ö. Synthesis of mesoporous $\mathrm{LiMn}_{2} \mathrm{O}_{4}$ and 
$\mathrm{LiMn}_{2-\mathrm{x}} \mathrm{Co}_{\mathrm{x}} \mathrm{O}_{4}$ thin films using the MASA approach as efficient water oxidation electrocatalysts. J. Mater. Chem. A 2018, 6, 13925-13933.

(27) Amirzhanova, A.; Karakaya, I.; Uzundal, C. B.; Karaoğlu, G.; Karadas, F.; Ülgüt, B.; Dag, Ö. Synthesis and water oxidation electrocatalytic and electrochromic behaviours of mesoporous nickel oxide thin film electrodes. J. Mater. Chem. A 2019, 7, 22012-22020.

(28) Amirzhanova, A.; Akmansen, N.; Karakaya, I.; Dag, Ö. Mesoporous $\mathrm{MnCo}_{2} \mathrm{O}_{4}, \mathrm{NiCo}_{2} \mathrm{O}_{4}$, and $\mathrm{ZnCo}_{2} \mathrm{O}_{4}$ thin-film electrodes as electrocatalysts for the oxygen evolution reaction in alkaline solutions. ACS Appl. Energy Mater. 2021, 4, 2769-2785.

(29) Çelik, Ö.; Dag, Ö. A new lyotropic liquid-crystalline phase is formed from oligo- (ethylene oxide) surfactants and $\left[\mathrm{M}\left(\mathrm{H}_{2} \mathrm{O}\right)_{\mathrm{n}}\right] \mathrm{X}_{\mathrm{m}}$, transition metal complexes. Angew. Chem., Int. Ed. 2001, 40, 38003803.

(30) Albayrak, C.; Soylu, A. M.; Dag, Ö. Lyotropic liquid-crystalline mesophases of $[\mathrm{Zn}(\mathrm{H} 2 \mathrm{O}) 6](\mathrm{NO} 3) 2-\mathrm{C} 12 \mathrm{EO} 10-\mathrm{CTAB}-\mathrm{H} 2 \mathrm{O}$ and $[\mathrm{Zn}(\mathrm{H} 2 \mathrm{O}) 6](\mathrm{NO} 3) 2-\mathrm{C} 12 \mathrm{EO} 10-\mathrm{SDS}-\mathrm{H} 2 \mathrm{O}$ systems. Langmuir 2008, 24, 10592-10595.

(31) Albayrak, C.; Özkan, N.; Dag, Ö. Origin of lyotropic liquid crystalline mesophase formation and liquid crystalline to mesostructured solid transformation in the metal nitrate salt- surfactant systems. Langmuir 2011, 27, 870-873.

(32) Rodriguez, C.; Kunieda, H. Effect of electrolytes on discontinuous cubic phases. Langmuir 2000, 16, 8263-8269.

(33) Klaus, A.; Tiddy, G. J. T.; Solans, C.; Harrar, A.; Touraud, D.; Kunz, W. Effect of salts on the phase behavior and the stability of nano-emulsions with rapeseed oil and an extended surfactant. Langmuir 2012, 28, 8318-8328.

(34) Mitchell, J. D.; Tiddy, G. J. T.; Waring, L.; Bostock, T.; McDonald, M. P. Phase behavior of polyethylene surfactants with water. Mesophase structures and partial miscibility (cloud points). J. Chem. Soc., Faraday Trans. 1 1983, 79, 975-1000.

(35) Sakya, P.; Seddon, J. M.; Templer, R. H.; Mirkin, R. J.; Tiddy, G. J. T. Micellar cubic phases and their structural relationships: The nonionic surfactant system $\mathrm{C}_{12} \mathrm{EO}_{12} /$ water. Langmuir 1997, 13, $3706-3714$

(36) Hofmeister, F. Zur lehre von der wirkung der salze. NaunynSchmiedeberg's Arch. Pharmacol. 1888, 25, 1-30.

(37) Gibb, B. C. Hofmeister's curse. Nat. Chem. 2019, 11, 963-965.

(38) Zhang, Y.; Cremer, P. S. Interactions between macromolecules and ions: the Hofmeister series. Curr. Opin. Chem. Biol. 2006, 10, 658-663.

(39) Zhang, Y.; Furyk, S.; Bergbreiter, D. E.; Cremer, P. S. Specific ion effects on the water solubility of macromolecules: PNIPAM and the Hofmeister series. J. Am. Chem. Soc. 2005, 127, 14505-14510.

(40) Ashraf, H.; Guo, Y.; Wang, N.; Pang, S.; Zhang, Y. Hygroscopicity of Hofmeister salts and glycine aerosols-salt specific interactions. J. Phys. Chem. A 2021, 125, 1589-1597.

(41) Bruce, E. E.; Okur, H. I.; Stegmaier, S.; Drexler, C. I.; Rogers, B. A.; van der Vegt, N. F. A.; Roke, S.; Cremer, P. S. Molecular mechanism for the interactions of Hofmeister cations with macromolecules in aqueous Solution. J. Am. Chem. Soc. 2020, 142, 1909419100.

(42) Okur, H. I.; Hladílková, J.; Rembert, K. B.; Cho, Y.; Heyda, J.; Dzubiella, J.; Cremer, P. S.; Jungwirth, P. Beyond the Hofmeister Series: Ion-Specific Effects on Proteins and Their Biological Functions. J. Phys. Chem. B 2017, 121, 1997-2014.

(43) Marcus, Y. Effect of ions on the structure of water: structure making and breaking. Chem. Rev. 2009, 109, 1346-1370.

(44) Gaiduk, A. P.; Galli, G. Local and global effects of dissolved sodium chloride on the structure of water. J. Phys. Chem. Lett. 2017, 8, $1496-1502$.

(45) Kang, B.; Tang, H.; Zhao, Z.; Song, S. Hofmeister series: insights of ion specificity from amphiphilic assembly and interface property. ACS Omega 2020, 5 (12), 6229-6239.

(46) Acharyya, A.; Mukherjee, D.; Gai, F. Assessing the effect of Hofmeister anions on the hydrogen-bonding strength of water via nitrile stretching frequency shift. J. Phys. Chem. B 2020, 124, 1178311792.
(47) Moghaddam, S. Z.; Thormann, E. The Hofmeister series: Specific ion effects in aqueous polymer solutions. J. Colloid Interface Sci. 2019, 555, 615-635.

(48) Hribar, B.; Southall, N. T.; Vlachy, V.; Dill, K. A. Ions affect the structure of water. J. Am. Chem. Soc. 2002, 124, 12302-12311.

(49) Salis, A.; Ninham, B. W. Models, and mechanisms of Hofmeister effects in electrolyte solutions, and colloid and protein systems revisited. Chem. Soc. Rev. 2014, 43, 7358-7377.

(50) Jungwirth, P.; Tobias, D. J. Specific ion effects at the air/water interface. Chem. Rev. 2006, 106, 1259-1281.

(51) Richmond, G. L. Molecular bonding and interactions at aqueous surfaces as probed by vibrational sum frequency spectroscopy. Chem. Rev. 2002, 102, 2693-2724.

(52) Noah-Vanhoucke, J.; Smith, J. D.; Geissler, P. L. Statistical mechanics of sum frequency generation spectroscopy for the liquidvapor interface of dilute aqueous salt solutions. Chem. Phys. Lett. 2009, 470, 21-27.

(53) Seki, T.; Sun, S.; Zhong, K.; Yu, C.-C.; Machel, K.; Dreier, L. B.; Backus, E. H. G.; Bonn, M.; Nagata, Y. Unveiling heterogeneity of interfacial water through the water bending mode. J. Phys. Chem. Lett. 2019, 10, 6936-6941.

(54) Seki, T.; Chiang, K.-Y.; Yu, C.-C.; Yu, X.; Okuno, M.; Hunger, J.; Nagata, Y.; Bonn, M. The Bending Mode of Water: A Powerful Probe for Hydrogen Bond Structure of Aqueous Systems. J. Phys. Chem. Lett. 2020, 11, 8459-8469.

(55) Greenspan, L. Humidity fixed points of binary saturated aqueous solutions. J. Res. Natl. Bur. Stand., Sect. A 1977, 81A, 89-96.

(56) Dag, Ö.; Alayoğlu, S.; Uysal, I. Effects of ions on the liquid crystalline mesophase of transition-metal salt:surfactant $\left(\mathrm{C}_{\mathrm{n}} \mathrm{EO}_{\mathrm{m}}\right) . J$. Phys. Chem. B 2004, 108, 8439-8446.

(57) Sorenson, G. P.; Schmitt, A. K.; Mahanthappa, M. K. Discovery of a tetracontinuous, aqueous lyotropic network phase with unusual 3D-hexagonal symmetry. Soft Matter 2014, 10, 8229-8235.

(58) Albayrak, C.; Barim, G.; Dag, Ö. Lyotropic liquid crystal to soft mesocrystal transformation in hydrated salt-surfactant mixtures. Chem. - Eur. J. 2013, 19, 15026-15035.

(59) Topuzlu, E. Y.; Ulgut, B.; Dag, Ö. Role of water in the lyotropic liquid crystalline lithium iodide-iodine-water- $\mathrm{C}_{12} \mathrm{E}_{10}$ mesophase as a gel electrolyte in a dye-sensitized solar cell. Langmuir 2021, 37, 83058313.

(60) Ni, Y.; Skinner, J. L. IR and SFG vibrational spectroscopy of the water bend in the bulk liquid and at the liquid-vapor interface, respectively. J. Chem. Phys. 2015, 143, 014502.

(61) Falk, M. The frequency of the $\mathrm{H}-\mathrm{O}-\mathrm{H}$ bending fundamental in solids and liquids. Speclrochimica Acta 1984, 40A, 43-48.

(62) Ichikawa, T.; Yoshio, M.; Hamasaki, A.; Mukai, T.; Ohno, H.; Kato, T. Self-organization of room-temperature ionic liquids exhibiting liquid-crystalline bicontinuous cubic phases: Formation of nano-ion channel networks. J. Am. Chem. Soc. 2007, 129, 1066210663.

(63) Lee, K.-K.; Park, K.-H.; Kwon, D.; Choi, J.-H.; Son, H.; Park, S.; Cho, M. Ion-pairing dynamics of $\mathrm{Li}^{+}$and $\mathrm{SCN}^{-}$in dimethylformamide solution: Chemical exchange two-dimensional infrared spectroscopy. J. Chem. Phys. 2011, 134, 064506.

(64) Ji, M.; Hartsock, R. W.; Sung, Z.; Gaffney, K. J. Influence of solute-solvent coordination on the orientational relaxation of ion assemblies in polar solvents. J. Chem. Phys. 2012, 136, 014501.

(65) Fournier, J. A.; Carpenter, W.; De Marco, L.; Tokmakoff, A. Interplay of ion-water and water-water interactions within the hydration shells of nitrate and carbonate directly probed with 2D IR spectroscopy. J. Am. Chem. Soc. 2016, 138, 9634-9645. 